\title{
Deprivation-Induced Strengthening of Presynaptic and Postsynaptic Inhibitory Transmission in Layer 4 of Visual Cortex during the Critical Period
}

\author{
Marc Nahmani and Gina G. Turrigiano \\ Department of Biology and Center for Behavioral Genomics, Brandeis University, Waltham, Massachusetts 02454
}

Inhibition from fast-spiking (FS) interneurons plays a crucial role in shaping cortical response properties and gating developmental periods of activity-dependent plasticity, yet the expression mechanisms underlying FS inhibitory plasticity remain largely unexplored. In layer 4 of visual cortex (V1), monocular deprivation (MD) induces either depression or potentiation of FS to star pyramidal neuron $($ FS $\rightarrow$ SP) synapses, depending on the age of onset (Maffei et al., 2004, 2006). This reversal in the sign $(-$ to + ) of plasticity occurs on the cusp of the canonical critical period (CP). To investigate the expression locus behind this switch in sign of inhibitory plasticity, mice underwent MD during the pre-CP [eye-opening to postnatal day (p)17] or CP (p22-p25), and FS $\rightarrow$ SP synaptic strength within layer 4 was assessed using confocal and immunoelectron microscopy, as well as optogenetic activation of FS cells to probe quantal amplitude at $\mathrm{FS} \rightarrow$ SP synapses. Brief MD before p17 or p25 did not alter the density of FS $\rightarrow$ SP contacts. However, at the ultrastructural level, FS $\rightarrow$ SP synapses in deprived hemispheres during the $\mathrm{CP}$, but not the pre-CP or in $\mathrm{GAD}_{65}$ knock-out mice, had larger synapses and increased docked vesicle density compared with synapses from the nondeprived control hemispheres. Moreover, FS $\rightarrow$ SP evoked miniature IPSCs increased in deprived hemispheres when MD was initiated during the $\mathrm{CP}$, accompanied by an increase in the density of postsynaptic $\mathrm{GABA}_{\mathrm{A}}$ receptors at FS $\rightarrow$ SP synapses. These coordinated changes in FS $\rightarrow$ SP synaptic strength define an expression pathway modulating excitatory output during $\mathrm{CP}$ plasticity in visual cortex.

Key words: electron microscopy; fast-spiking; LTP; monocular deprivation; optogenetic; pyramidal

\section{Introduction}

Fast-spiking (FS) GABAergic interneurons are central regulators of cortical excitability whose rapid feedforward and feedback control over pyramidal cell firing can sharpen neuronal response properties, modulate cortical rhythms, and gate developmental periods of activity-dependent plasticity (Whittington et al., 1995; Huang et al., 1999; Gabernet et al., 2005; Lee et al., 2012). In keeping with these important roles in cortical function, the strength of FS synapses can be regulated in an activity-dependent manner to fine-tune inhibition during periods of robust circuit maturation, such as the visual system critical period (CP; Chattopadhyaya et al., 2004; Maffei et al., 2006). Determining how this inhibitory plasticity is expressed has important consequences for understanding how experience modulates neocortical circuit function, yet the underlying expression mechanisms remain poorly defined. Here we sought to determine how disruptions

Received Oct. 29, 2013; revised Dec. 31, 2013; accepted Jan. 7, 2014.

Author contributions: M.N. and G.T. designed research; M.N. performed research; M.N. analyzed data; M.N. and G.T. wrote the paper.

This work was supported by National Eye Institute-National Institutes of Health Grant R01 EY014439. We thank Dr. Takao Hensch for the $\mathrm{GAD}_{65} \mathrm{KO}$ mouse line, Dr. Josh Huang for the PV Cre line, and Evan Rosenberg for help with confocal analyses.

The authors declare no competing financial interests.

Correspondence should be addressed to Dr. Gina G. Turrigiano, Department of Biology, MS008, Brandeis University, 415 South Street, Waltham, MA 02454. E-mail: turrigiano@brandeis.edu.

DOI:10.1523/JNEUROSCI.4600-13.2014

Copyright $\odot 2014$ the authors $\quad 0270-6474 / 14 / 342571-12 \$ 15.00 / 0$ of visual function affect the strength of FS interneuron to star pyramidal $(\mathrm{FS} \rightarrow \mathrm{SP})$ synapses within layer 4 of primary visual cortex (V1).

FS interneurons have a protracted period of postnatal development in primary sensory cortex, reaching an adult-like physiological and anatomical state 3-4 weeks after birth (Okaty et al., 2009; Jiang et al., 2010; Lazarus and Huang, 2011; PangratzFuehrer and Hestrin, 2011). Interestingly, FS $\rightarrow$ SP long-term depression (LTD), long-term potentiation (LTP), and spike timing-dependent plasticity are expressed at distinct stages along this postnatal timeline, suggesting that inhibitory plasticity is tuned to interneuron identity and age of the cortex (Maffei et al., 2004, 2006; Yazaki-Sugiyama et al., 2009; Lamsa et al., 2010; House et al., 2011; Lefort et al., 2013). A striking example of such developmental regulation of FS $\rightarrow$ SP plasticity is observed in L4 of $\mathrm{V} 1$ in response to short-duration (2-3 d) monocular deprivation (MD). This paradigm induces depression at FS $\rightarrow$ SP synapses during an early "pre-critical period" (CP; Maffei et al., 2004), but potentiation during the CP (Maffei et al., 2006). This reversal in the sign ( - to + ) of plasticity occurs on the cusp of the canonical $\mathrm{CP}$, and potentiation of inhibition during the CP likely contributes to the cortical response depression observed after brief MD (Maffei et al., 2006). Uncovering the unique expression mechanism(s) that underlie this form of inhibitory plasticity will aid in understanding how FS interneurons contribute to the dynamic modulation of cortical responses. 
To determine the expression mechanisms of FS $\rightarrow$ SP plasticity, we monocularly deprived mice for $3 \mathrm{~d}$ during either the pre-CP or the $\mathrm{CP}$. We then quantified changes in presynaptic and postsynaptic function, using a combination of confocal and immunoelectron microscopy, as well as optogenetic activation of FS cells to probe quantal amplitude at $\mathrm{FS} \rightarrow \mathrm{SP}$ synapses. Our data show that MD during the $\mathrm{CP}$ (but not the pre- $\mathrm{CP}$ ) produces coordinated changes in presynaptic and postsynaptic function that cooperate to enhance FS $\rightarrow$ SP synaptic strength. Further, we show that a genetic manipulation that prevents the initiation of $\mathrm{CP}$ plasticity $\left[\mathrm{GAD}_{65}\right.$ knock-out $\left.\left(\mathrm{GAD}_{65} \mathrm{KO}\right)\right]$ prevents these MD-induced changes in FS $\rightarrow$ SP synaptic strength. These findings identify an expression pathway modulating FS synaptic strength during $\mathrm{CP}$ plasticity in visual cortex.

\section{Materials and Methods}

All experimental procedures used in this study were approved by the Institutional Animal Care and Use Committee at Brandeis University and followed the guidelines of the National Institutes of Health.

Animals. Male C57BL/6J mice between postnatal day (p)15 and p26 were used throughout confocal and immunoelectron microscopy experiments (referred to as wild-type) unless otherwise stated. Male homozygous mice lacking the $65 \mathrm{kDa}$ isoform of glutamic acid decarboxylase $\left(\mathrm{GAD}_{65} \mathrm{KO}\right.$ mice; Hensch et al., 1998) were used at ages commensurate with wild-type experiments as stated in Results. Mice expressing a loxPflanked STOP cassette upstream of the ChR2(H134R)-EYFP fusion gene (Ai32 line, stock \#012569; Jackson Laboratories) were mated to a line of homozygous mice in which Cre-recombinase was knocked-in to the parvalbumin locus (PV ${ }^{\text {cre }}$; Hippenmeyer et al., 2005). Male mice heterozygous for channelrhodopsin (ChR2) alleles were used $\left(\mathrm{ChPV}^{+/-}\right)$for all electrophysiology experiments.

Perfusions. Transcardial perfusions were performed for confocal and electron microscopy experiments. Mice were deeply anesthetized with a mixture of ketamine, xylazine, and acepromazine, and monitored until spinal and corneal reflexes were absent. Mice were then perfused transcardially with Tyrode's solution, $\mathrm{pH} 7.4$, followed by filtered $4 \%$ paraformaldehyde plus $0.5 \%$ glutaraldehyde in PBS, $\mathrm{pH}$ 7.4. Next, brains were immersed in $4 \%$ paraformaldehyde overnight at $4^{\circ} \mathrm{C}$, and then 50 $\mu \mathrm{m}$ coronal sections were cut on a vibrating microtome (Leica VT1000S). Floating sections containing monocular visual cortex (V1m) were rinsed in $0.01 \mathrm{~m}$ PBS, immersed in solution containing $1 \% \mathrm{NaBH}_{4}$ in $0.1 \mathrm{M}$ phosphate buffer for $30 \mathrm{~min}$, and then rinsed at least 4 times in PBS before storage or use.

Monocular deprivation. Mice were monocularly deprived as previously described (Maffei et al., 2004, 2006, 2010). Briefly, mice were anesthetized with a mixture of ketamine, xylazine, and acepromazine until pain reflexes were lost, kept warm, and monitored for body temperature. Next, a topical analgesic was applied and mice had their right eyelid sutured using a vertical mattress technique. Any mice with signs of infection during or after MD were not used for experiments. Mice were monocularly deprived for $3 \mathrm{~d}$ immediately before eye opening, or from p $22 / 23$ to p25/26. To monocularly deprive mice immediately before eye opening, litters were routinely checked for signs of single pups opening one eye. Because different litters, as well as mice within a single litter, had eye opening times that varied by $\sim 1.5-2 \mathrm{~d}$, mice had their right eye sutured from approximately p12 to p14 and were then deprived for $3 \mathrm{~d}$ until p15-p17.

Immunofluorescence. Floating sections containing monocular visual cortex $(\mathrm{V} 1 \mathrm{~m})$ were rinsed at least three times in PBS and then immersed in primary antibodies containing $1 \%$ bovine serum albumin (BSA), $0.1 \%$ Triton X-100, and $0.05 \% \mathrm{NaN}_{3}$ in PBS within glass scintillation vials for $36-48 \mathrm{~h}$ on a rotating shaker at room temperature. After primary incubation, sections were washed three times in PBS and then incubated in secondary antibodies containing $1 \%$ BSA for $2 \mathrm{~h}$ on a rotating shaker at room temperature. Primary antibodies consisted of rabbit anti-parvalbumin (1:7000, PV28; Swant), mouse anti-NeuN (1:700, MAB377; Millipore), and mouse anti-GFP (for EYFP-tagged ChR2;
1:400, A-11120; Invitrogen). Secondary antibodies consisted of antirabbit Alexa Fluor 488 (1:400; Invitrogen) and anti-mouse Alexa Fluor 568 (1:400; Invitrogen).

Confocal microscopy and analysis. Labeled sections were mounted on slides with an anti-fade medium (Fluoromount-G; SouthernBiotech), coverslipped, and imaged on a Leica SP2 or SP5. Image stacks were obtained using a $63 \times 1.4$ NA PLAN APO oil-immersion objective, at a zoom of $2-3 \times$, an optical section height $(z$-step) of $0.2 \mu \mathrm{m}$, and at $1024 \times 1024$ resolution. These parameters enabled sampling above the Nyquist criterion for FS parvalbumin-immunoreactive (PV-ir) perisomatic boutons with average cross section areas of $\sim 0.33 \mu \mathrm{m}^{2}$ (see Fig. $2 B$ ) and volumes in excess of $1 \mu \mathrm{m}^{3}$ (see Fig. $2 C$ ). To determine the density of PV-ir contacts surrounding NeuN-labeled pyramidal somata, we first drew masks that were $\sim 2 \mu \mathrm{m}$ from the borders of labeled pyramidal somata and used these masks as our somatic perimeter measurement. Next, we superimposed these masks onto single images of thresholded PV-ir labeling from the same optical sections (Li Threshold, ImageJ; Schneider et al., 2012). Within each image stack we randomly selected $4-5$ pyramidal somata, drawing masks around each soma at least four times in optical sections spaced $10 \mu \mathrm{m}$ apart in the $z$-dimension, through the depth of the stack. Thresholded PV-ir signal within the pyramidal masks were considered putative synaptic contacts. We initially compared an analysis of 5 stacks in which perisomatic PV-ir contacts were counted by eye, to the identical analysis performed by a constrained particle analysis function in ImageJ. There were no significant differences between these two analyses [ $p=0.6$, Kruskal-Wallis (KS) test; data not shown], and the average putative synaptic contact densities from both analyses were corroborated by counts of identified perisomatic PV-ir synapses under immunoelectron microscopy (see Fig. $2 A$ ). We therefore used the particle analysis function to determine contact density for all confocal experiments. In total, each developmental and MD time point consisted of 3 animals $\times 5$ image stacks/animal $\times 5$ cells/stack $\times 5$ optical sections/cell $=75$ cells ( 375 optical soma sections) per experimental time point. Putative synaptic PV-ir contact density was calculated for each soma as follows: Total soma section contacts/Total soma perimeter $\times 50$ (normalization to average soma perimeter).

Immunoelectron microscopy. Animals were perfused and sections were prepared as for confocal microscopy. After rinsing, sections were incubated in rabbit anti-parvalbumin (1:1000, PV28; Swant) in a solution containing $1 \% \mathrm{BSA}$ and $0.05 \% \mathrm{NaN}_{3}$ in PBS for at least $48 \mathrm{~h}$ on atating shaker at room temperature. Next, sections were rinsed in PBS and then incubated in anti-rabbit $1.4 \mathrm{~nm}-\mathrm{Au}$ secondary (1:100, catalog \#2003, Nanoprobes) in $1 \%$ BSA and $0.05 \% \mathrm{NaN}_{3}$ in PBS overnight on rotating shaker at room temperature. Then, sections were rinsed in PBS, incubated in $2 \%$ glutaraldehyde in $\mathrm{dH}_{2} \mathrm{O}$ for $15 \mathrm{~min}$, and then rinsed in citrate buffer, $\mathrm{pH} 6.5$, and $\mathrm{dH}_{2} \mathrm{O}$. Finally, sections were immersed in a silver enhancement medium (IntenSE M, GE Healthcare Life Sciences), rinsed in $\mathrm{dH}_{2} \mathrm{O}$ and citrate buffer, and prepared for electron microscopy (EM) processing. EM processing was performed according to previously published protocols (Nahmani and Erisir, 2005; Coleman et al., 2010). Briefly, sections were dehydrated in a series of ethanol dilutions and acetone and embedded in an epoxy resin. Resin blocks containing V1m sections were then cured in a $55-57^{\circ} \mathrm{C}$ oven until blocks obtained the desired consistency. Cured blocks were carefully trimmed to a $\leq 1 \mathrm{~mm} \times$ $\sim 0.3 \mathrm{~mm}$ trapezoid centered in layer 4 of V1m. Next, blocks were sectioned on an ultramicrotome (EM UC7, Leica Microsystems) at $70 \mathrm{~nm}$, and collected on either 200 mesh $\mathrm{Cu}$ or Ni Formvar-coated EM grids. To perform postembedding for $\mathrm{GABA}_{\mathrm{A}}$ receptor $\left(\mathrm{GABA}_{\mathrm{A}} \mathrm{R}\right) \gamma 2$-subunits, sections were collected on Ni Formvar-coated slot grids and then washed in Tris-buffered saline (TBS, pH7.4) containing 0.1\% Triton X-100 for $15 \mathrm{~min}$. Grids were then washed several times in TBS and then incubated in mouse monoclonal anti- $\gamma 2$ primary antibody (1:200, catalog \#MABN263; Millipore) in TBS, pH 7.4, for $2 \mathrm{~h}$ or overnight in a humid chamber. Next, grids were rinsed in TBS, $\mathrm{pH} 7.4$, and then rinsed in TBS, $\mathrm{pH}$ 8.2, before being incubated in anti-mouse $5 \mathrm{~nm}$-Au secondary (1:50, catalog \#15980; Ted Pella) in TBS, pH 8.2, for $1 \mathrm{~h}$. Next, grids were rinsed in TBS, $\mathrm{pH} \mathrm{7.4}$, postfixed in $2 \%$ glutaraldehyde for $10 \mathrm{~min}$, rinsed in $\mathrm{dH}_{2} \mathrm{O}$, and allowed to air dry. Finally, grids were incubated in a lead citrate solution for 4-5 min before being rinsed in $\mathrm{dH}_{2} \mathrm{O}$ and air-dried. 
Electron microscopy image analysis. Sections were prepared for EM and imaged on either a Morgagni (FEI) or F20 (FEI) electron microscope at a magnification of $13-32 \mathrm{~K}$, using a $1 \mathrm{k} \times 1 \mathrm{k}$ or $2 \mathrm{k} \times 2 \mathrm{k}$ digital camera, corresponding to final pixel sizes of $1.5-0.6 \mathrm{~nm}$. For FS $\rightarrow$ SP synaptic ultrastructure analyses, somata with pyramidal morphology were randomly chosen within layer 4, and PV-ir perisomatic boutons were deemed synaptic if the following conditions were met: (1) there was parallel alignment of presynaptic and postsynaptic membranes, (2) presence of at least 3 presynaptic vesicles, and (3) presence of a visible postsynaptic density. PV-ir terminals were considered "PV-positive" if their gold particle density was $>99^{\text {th }}$ percentile for gold labeling density within the cytoplasm of abutting pyramidal neurons considered nonspecific labeling [average gold density $\left(\right.$ particles $\left./ \mu \mathrm{m}^{2}\right): \mathrm{p} 17$ terminals $=$ $43 \pm 0.4$ vs p17 somata $=1 \pm 0.2 ;$ p 25 terminals $=69 \pm 5$ vs p 25 somata $=2 \pm 0.2$ ). Presynaptic vesicles were deemed "docked" if they were $\leq 2 \mathrm{~nm}$ from the presynaptic membrane (Fernández-Busnadiego et al., 2010; Siksou et al., 2011), and considered part of the readily releasable pool if they were within $200 \mathrm{~nm}$ of the presynaptic membrane (Darcy et al., 2006). Reconstruct software was used for PV-ir FS terminal serial EM reconstructions (Fiala, 2005; Harris et al., 2006). For $\mathrm{GABA}_{\mathrm{A}} \mathrm{R} \gamma 2$ subunit analysis, PV-positive terminals were identified as described above, while $\gamma 2$-gold labeling was deemed synaptic if the center of gold particles was within $40 \mathrm{~nm}$ in axo-somatic distance from the centroid of the synaptic cleft. This distance was chosen based on the maximal distance that a membrane or postsynaptic density-bound gold label could extend into or away from the average-sized FS $\rightarrow$ SP synaptic cleft $(\sim 20$ $\mathrm{nm}$ ), given the size of the primary and secondary antibodies coupled to a $5 \mathrm{~nm}$ gold particle $(\sim 15-22 \mathrm{~nm})$ and thickness of the membrane/postsynaptic density ( $\sim 5 \mathrm{~nm}$; Werner et al., 1972; Hainfeld and Furuya, 1992; Harris et al., 1992). In addition, gold particles were only deemed synaptic if they were contained within (postsynaptic) or directly parallel to (presynaptic) the postsynaptic density. $\mathrm{GABA}_{\mathrm{A}} \mathrm{R} \gamma 2$-subunit density was calculated as follows: number of gold particles/length of postsynaptic density.

Electrophysiology. Coronal brain slices $(300 \mu \mathrm{m})$ were obtained from $\mathrm{ChPV}^{+/-}$mice as previously described (Maffei et al., 2006, 2010). Chilled artificial CSF (ACSF) was continuously oxygenated and contained the following in (mM): $126 \mathrm{NaCl}, 3 \mathrm{KCl}, 2 \mathrm{MgCl}_{2}, 1 \mathrm{NaH}_{2} \mathrm{PO}_{4}, 25$ $\mathrm{NaHCO}_{3}, 2 \mathrm{CaCl}_{2}$, and 25 dextrose. Coronal slices were sectioned on a VT1000S vibrating microtome (Leica Microsystems), placed on a semipermeable membrane, and incubated in continuously oxygenated ACSF at $37^{\circ} \mathrm{C}$ for $30 \mathrm{~min}$, and then incubated at room temperature until they were placed in a recording chamber.

To record FS $\rightarrow$ SP miniature IPSCs (mIPSCs), slices were placed in the recording chamber and incubated in strontium ACSF at $34^{\circ} \mathrm{C}$ containing (in mM): $126 \mathrm{NaCl}, 3 \mathrm{KCl}, 1.3 \mathrm{MgCl}_{2}, 1 \mathrm{NaH}_{2} \mathrm{PO}_{4}, 25 \mathrm{NaHCO}_{3}, 4 \mathrm{SrCl}_{2}$, and 25 dextrose, as well as $50 \mu \mathrm{M} \mathrm{APV}$ and $20 \mu \mathrm{M}$ DNQX for at least 20 min before recording. Spontaneous and evoked mIPSCs were recorded using a near "symmetric" internal recording solution containing (in mM): $120 \mathrm{KCl}, 10 \mathrm{~K}$-HEPES, 0.5 EGTA, 4 Mg-ATP, 0.3 Na-GTP, 10 $\mathrm{Na}$-phosphocreatine, 10 sucrose, and $0.2 \%$ biocytin.

Neurons with pyramidal morphology were located in the center of layer 4 of V1m and visualized using a $40 \times$ water-dipping objective from an Olympus BX51WI microscope with DIC optics and a custom laser mount. Pyramidal neurons were identified by the presence of an apical dendrite, teardrop-shaped soma, and stereotypical regular-spiking phenotype. Pyramidal morphology and location within layer 4 of V1m was confirmed by post hoc reconstruction of biocytin fills; any cells not meeting the above criteria were excluded from analyses. For mIPSC recordings, pyramidal neurons were voltage-clamped at -70 $\mathrm{mV}$ in oxygenated strontium $\operatorname{ACSF}\left(34^{\circ} \mathrm{C}\right)$, and eight $5 \mathrm{~ms}, 473 \mathrm{~nm}$ laser pulses ( $1.5 \mathrm{~mW}$ at sample, $\sim 28 \mu \mathrm{m}$ spot) centered on the pyramidal soma were delivered at $10 \mathrm{~Hz}$. In current clamp, EYFP-labeled FS interneurons reliably followed each laser pulse with a spike at this laser power and frequency (see Fig. 4D). Detection criteria for mIPSCs included $>7 \mathrm{pA}$ and $10-90 \%$ rise times $<3 \mathrm{~ms}$; all reported rise times were $10-90 \%$. Neurons with resting membrane potentials more positive than $-60 \mathrm{mV}$, input resistance $<80 \mathrm{M} \Omega$, or series resistance $>20 \mathrm{M} \Omega$ were excluded from analyses.
Statistics. All results are expressed as mean \pm SEM. Wilcoxon nonparametric tests were performed on all comparisons unless otherwise noted, with significance levels set at $p<0.05$.

\section{Results}

FS $\rightarrow$ SP contact density parallels functional maturation

FS synapses in rodent V1 undergo significant maturation in the first weeks of life (Chattopadhyaya et al., 2004; Okaty et al., 2009; Jiang et al., 2010; Pangratz-Fuehrer and Hestrin, 2011). To characterize the morphological correlates of this maturation, we began by quantifying the developmental and experience-dependent regulation of the number of putative synaptic contacts between FS interneuron and star pyramidal cells $(\mathrm{FS} \rightarrow \mathrm{SP})$ in layer 4 of V1m (Fig. 1A). Parvalbumin-immunoreactive (PV-ir) FS interneurons in V1 form perisomatic basket-like terminals around pyramidal somata and proximal dendrites, ensheathing these cells in a net of boutons and en-passant synapses (Holländer and Vanegas, 1981; DeFelipe and Fairén, 1982; Somogyi et al., 1983; Czeiger and White, 1997; Fig. 1B,C). We used confocal microscopy to quantify the density of PV-ir FS putative synaptic contacts onto star pyramid neuron somata within single optical sections, identified using the layer 4 pyramidal-specific somatic marker NeuN (Chattopadhyaya et al., 2004; Fig. 1C; see Materials and Methods). Throughout all of our experiments, analyses were performed in layer 4 of V1m, enabling us to use the ipsilateral nondeprived V1m hemisphere in the same animals as control tissue. Here and for all experiments described below, data were analyzed blind to experimental condition.

Just after eye opening at p15, layer 4 pyramidal neurons were contacted by $5.3 \pm 0.5 \mathrm{FS}$ puncta per $50 \mu \mathrm{m}$ of somatic perimeter (Fig. 1D). By p17, FS contact density increased significantly to $\sim 136 \%$ of $p 15$ levels $(p<0.001$, one-way ANOVA; $p=0.002$ for p15 vs p17, Tukey's post hoc test). After p17, contact numbers remained stable and were not significantly different from p17 levels at either p22 or p25 ( $p \geq 0.2$, Tukey's post hoc test). This developmental profile for FS contact density nicely matches the intrinsic physiological maturation of these FS interneurons (Okaty et al., 2009) and the development of GABAergic synaptic strength onto layer 4 pyramidal neurons in mouse V1 (Jiang et al., 2010).

\section{Brief MD has no effect on FS $\rightarrow$ SP contact density}

Brief MD depresses FS $\rightarrow$ SP synaptic strength during the pre-CP, but potentiates transmission at this synapse during the CP (Maffei et al., 2004, 2006, 2010). Moreover, these changes in strength are accompanied by changes in the coefficient of variation (CV), suggesting a presynaptic component to this form of inhibitory plasticity (Maffei et al., 2006). Interestingly, these changes in CV are not accompanied by changes in short-term plasticity, suggesting they do not arise through changes in release probability (Maffei et al., 2004, 2006). One straightforward explanation for these results is that $\mathrm{MD}$ decreases the number of $\mathrm{FS} \rightarrow \mathrm{SP}$ connections before $\mathrm{CP}$ onset, and has the opposite effect during the CP. To examine this possibility, we performed MD on wild-type mice for $3 \mathrm{~d}$ during the pre-CP (from just before eye opening to p15-p17), and during the classical visual system CP (from p22/23 to p25/26; Fig. 1A). Since eye opening varied within and across litters by $\sim 2$ $\mathrm{d}$ (p12-p14), pre-CP brains were examined between p15 and p17. Three days of MD had no effect on FS $\rightarrow$ SP contact density between the control and deprived hemispheres at either p17 ( $p=$ $0.4)$ or $\mathrm{p} 25(p=0.5$; Fig. $1 E)$. These data suggest that brief MD does not modulate synaptic strength by changing the number of $\mathrm{FS} \rightarrow \mathrm{SP}$ contacts at either developmental stage. 
MD at p25 increases the density of docked vesicles at $\mathrm{FS} \rightarrow \mathrm{SP}$ synapses A change in the CV could be caused by changes in the number of functional release sites per bouton, even if bouton density does not change. Accordingly, we monocularly deprived mice as above and performed immuno-EM to visualize the fine structure of FS $\rightarrow$ SP synapses. To examine $\mathrm{FS} \rightarrow \mathrm{SP}$ synaptic ultrastructure, pyramidal somata were chosen at random within embedded ultrathin sections of layer $4 \mathrm{~V} 1 \mathrm{~m}$, and high-magnification images were taken of synaptic $\mathrm{PV}$-ir perisomatic FS $\rightarrow$ SP synapses (Fig. $2 A, B$ ). We examined these synapses for morphological correlates of synaptic strength such as the size of the readily releasable pool (vesicles $\leq 200 \mathrm{~nm}$ from the presynaptic membrane) and number of presynaptic docked vesicles (Murthy et al., 2001; Branco et al., 2010; Holderith et al., 2012), as well as the size of the postsynaptic density (Rutledge, 1978; Desmond and Levy, 1983; Ostroff et al., 2002; Harris et al., 2003). In addition, we reconstructed several FS boutons by serial section-EM and found that single FS PV-ir terminals often covered large perisomatic regions (Fig. $2 C)$, confirming our approach of classifying contiguous labeled regions as single $\mathrm{FS} \rightarrow \mathrm{SP}$ putative synapses at confocal resolution (see Materials and Methods; Fig. $1 B, C)$.

In the control hemisphere of wild-type animals, both synapse cross-section length $(121 \%)$ and presynaptic terminal area (119\%) increased over postnatal development (p17 vs p25, $p=0.005$ for synapse length; terminal area: p17, $0.27 \pm 0.02$ $\mu \mathrm{m}^{2}$ vs p $25,0.33 \pm 0.02 \mu \mathrm{m}^{2}, p=0.006$; $n=65$ and 89, respectively; Fig. $3 A$ ). Interestingly, although the size of the readily releasable pool increased with terminal size at $\mathrm{p} 25(150 \%, p=0.008)$, the number and density of docked vesicles remained steady over development ( $p=0.67$ and 0.08 , respectively; Fig. $3 \mathrm{~B}, \mathrm{C})$. Thus, although the density of $\mathrm{FS} \rightarrow \mathrm{SP}$ putative synapses does not increase significantly from p17 to p25, over the same developmental period these synapses grow larger and are endowed with a larger vesicle pool.

Next, we asked whether MD alters FS synaptic ultrastructure. During the pre-CP, brief MD had no effect on any of the morphological features of FS synapses we measured, including terminal area, synapse length, and the number of docked vesicles (control, $n=66$; deprived, $n=65$ synapses, $p \geq 0.2$; Fig. $3 A-C$ ). In contrast, in animals deprived for $3 \mathrm{~d}$ during the $\mathrm{CP}, \mathrm{FS} \rightarrow \mathrm{SP}$ synapses in the deprived hemisphere had larger postsynaptic densities (control vs deprived, $n=89$ and $n=95$, respectively; $p=$ 0.004 ; Fig. $3 A$ ), increased numbers of docked vesicles per FS terminal $(p=0.001$; Fig. $3 B)$, and a commensurate increase in the density of docked vesicles at those larger synapses $(p=0.04$; Fig. 3D). Hence, brief MD during the $\mathrm{CP}$ increases the number of

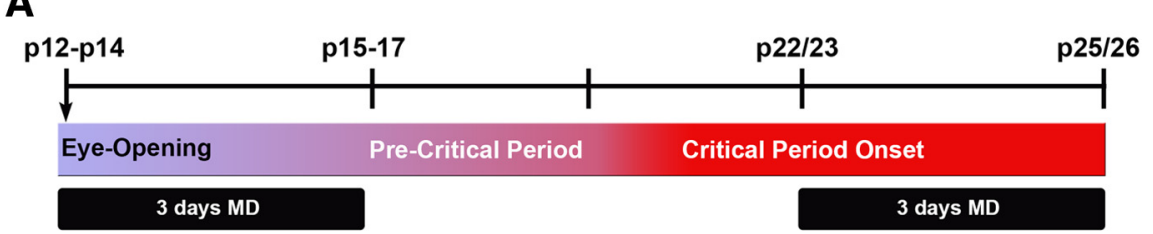

B

C

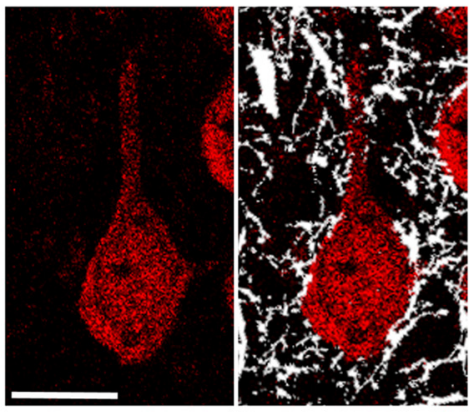

E

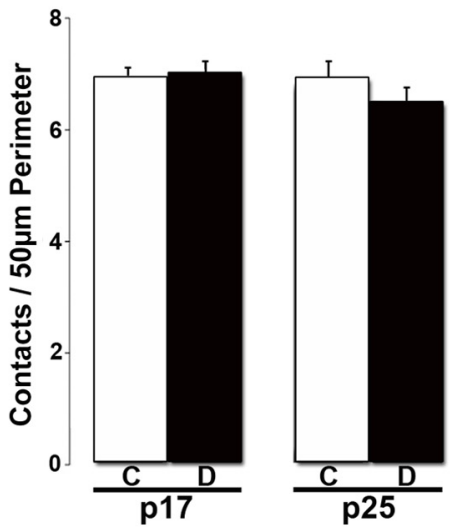

Figure 1. Brief MD does not affect FS $\rightarrow$ SP contact density. $A$, Time course for developmental and MD analyses used for all experiments. $\boldsymbol{B}$, Three-dimensional projection of a confocal stack, showing a single PV-ir FS interneuron (green) contacting NeuN-labeled pyramidal somata (red) in layer 4 of V1m. Inset shows zoomed-in z-projection of boxed pyramidal cell displaying neuron with superimposed PV-ir thresholded labeling used for contact density quantification (right). D, Development of perisomatic PV-ir FS contact density with pyramidal cells in layer 4. E, FS $\rightarrow$ SP contact density during the pre-CP (p17) and CP (p25), in control ( $\boldsymbol{C}$ ) and deprived (D) hemispheres. Scale bars: $\boldsymbol{B}$, inset, $5 \mu \mathrm{m} ; \boldsymbol{B}, \boldsymbol{C}, 15 \mu \mathrm{m}$. ${ }^{*} p<0.05$.

presynaptic release sites, which likely contributes to the MDinduced potentiation of transmission at this synapse (Maffei et al., 2006).

To determine whether these experience-dependent changes in FS synapse morphology were tied to the onset of the $\mathrm{CP}$, we monocularly deprived $\mathrm{GAD}_{65} \mathrm{KO}$ mice and measured the same synaptic parameters. These mice are profoundly deficient in the rate-limiting enzyme for GABA synthesis in presynaptic terminals and are unable to engage the necessary processes to trigger CP plasticity (Hensch et al., 1998). In contrast to the identical manipulation in wild-type animals, brief $\mathrm{MD}$ during the $\mathrm{CP}$ did not alter $\mathrm{FS} \rightarrow \mathrm{SP}$ synapse length in $\mathrm{GAD}_{65} \mathrm{KO}$ mice (control vs deprived, $n=66$ and 64 , respectively, $p=0.2$; Fig. $3 A$ ). In addition, rather than displaying an increase in docked vesicles, FS synaptic terminals from the deprived hemispheres of $\mathrm{GAD}_{65} \mathrm{KO}$ mice had significantly decreased numbers of docked vesicles compared with control hemispheres ( $p=0.03$; Fig. $3 B)$. Surpris- 
A

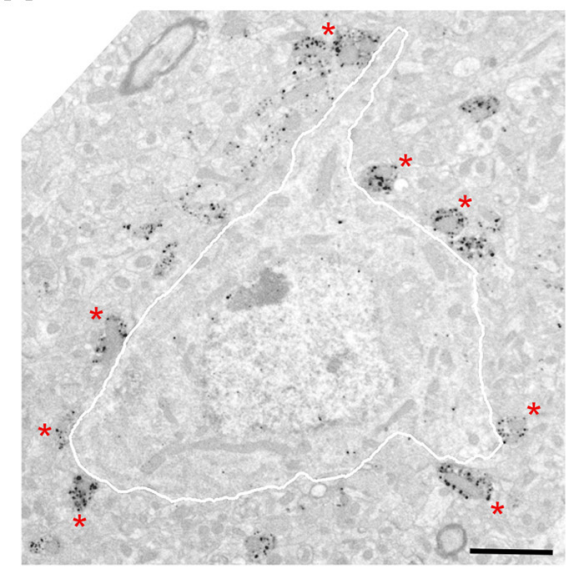

$\mathrm{C}_{1}$

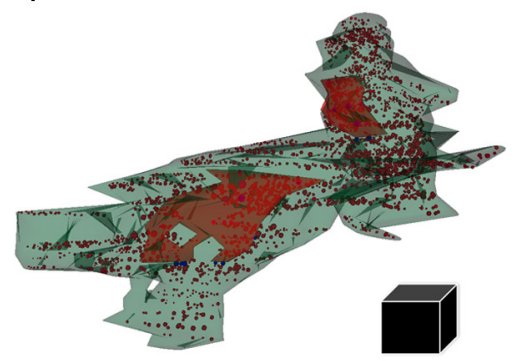

$\mathrm{C}_{2}$

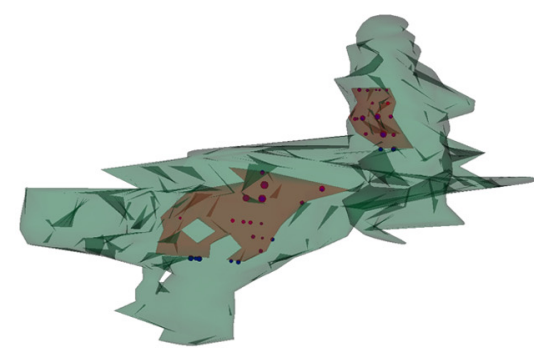

B

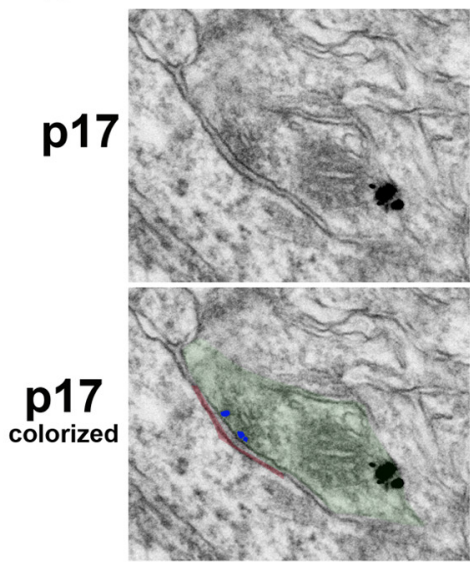

Control

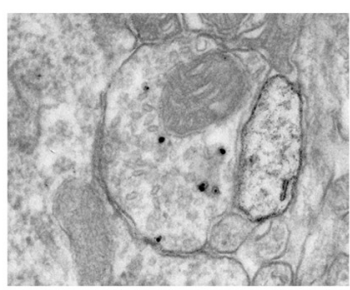

p25
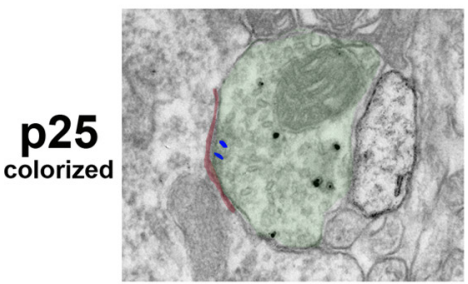

colorized
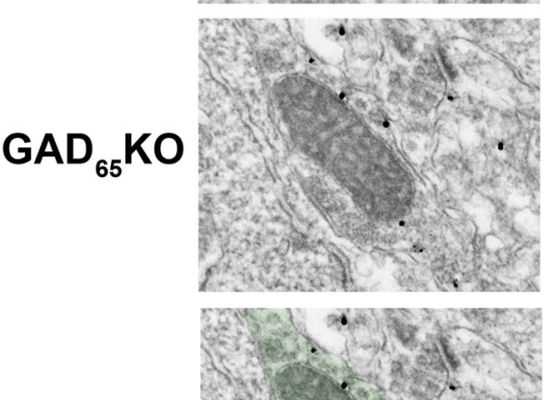

$\mathrm{GAD}_{65} \mathrm{KO}$

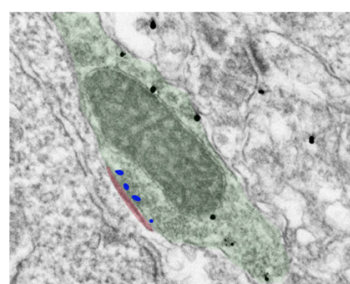

Deprived
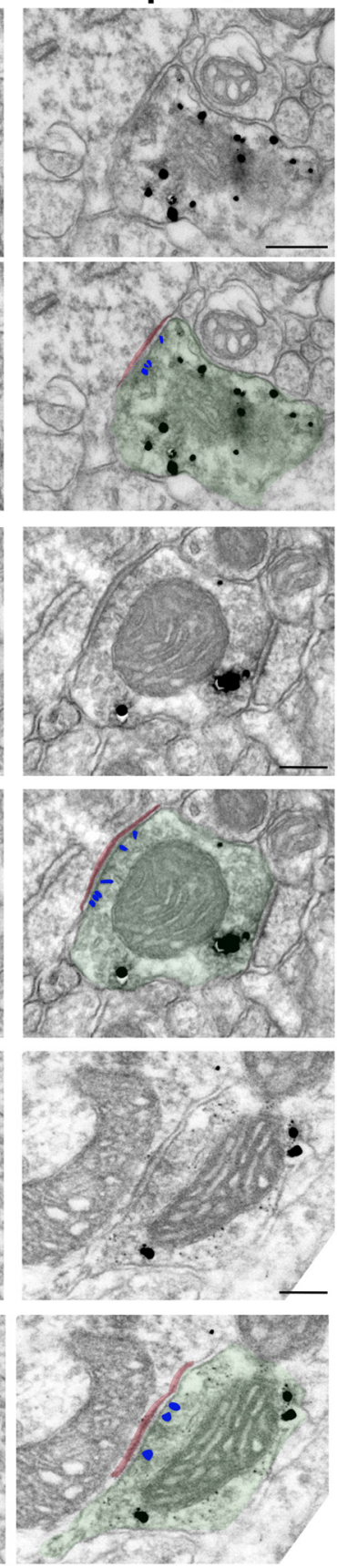

Figure 2. Examination of FS $\rightarrow$ SP synaptic ultrastructure. $A$, Low-magnification electron micrograph showing a layer 4 pyramidal soma (white outline) contacted by eight PV-ir perisomatic synaptic terminals (asterisks; silver-enhanced gold labeling). $\boldsymbol{B}$, Representative images of PV-ir FS $\rightarrow$ SP synapses at EM resolution in control and deprived hemispheres at p17 (wild-type) and p25 (wild-type and $\mathrm{GAD}_{65} \mathrm{KO}$ ). Lower "colorized" panels are duplicates of those above, highlighting FS boutons (green), postsynaptic densities (red), and docked vesicles (blue). Note that the PV-ir silver-enhanced gold particles within each bouton do not prevent analyses of synaptic ultrastructure. $\boldsymbol{C}$, Serial-section three-dimensional reconstruction of a synaptic $P$ V-ir perisomatic bouton. $\boldsymbol{C}_{\boldsymbol{1}}$, PV-ir bouton (green) displaying both undocked (red) and docked vesicles (blue), and forming two synapses (red) with a pyramidal soma (data not shown). $\boldsymbol{C}_{2}$, Same bouton as in $\boldsymbol{C}_{\mathbf{1}}$, displaying only docked vesicles. Scale bars: $\boldsymbol{A}, 2 \mu \mathrm{m} ; \boldsymbol{B}, 200 \mathrm{~nm} ; \boldsymbol{C}, 300 \mathrm{~nm}$.

ingly, FS terminals from deprived hemispheres in these mice contained approximately half the readily releasable vesicular pool of their control hemisphere counterparts ( $p<0.0001$; Fig. $3 C$ ), yet had similarly sized presynaptic terminals (control, $0.33 \pm 0.02$ $\mu \mathrm{m}^{2}$; deprived, $0.31 \pm 0.02 \mu \mathrm{m}^{2} ; p=0.1$ ). Together, these findings indicate that the same factors that prevent $\mathrm{GAD}_{65} \mathrm{KO}$ mice from displaying $\mathrm{MD}$-induced $\mathrm{CP}$ plasticity are sufficient to prevent the expression of MD-induced FS $\rightarrow$ SP morphological plasticity during the CP.

\section{MD during the $\mathrm{CP}$ increases $\mathrm{FS} \rightarrow \mathrm{SP}$ evoked mIPSCs}

In addition to changing the $\mathrm{CV}, \mathrm{MD}$-induced potentiation of $\mathrm{FS} \rightarrow \mathrm{SP}$ transmission during the $\mathrm{CP}$ is associated with an increase in the number of open $\mathrm{GABA}_{\mathrm{A}}$ Rs during evoked IPSCs (Maffei et al., 2006), suggesting a potential change in the number of synaptic $\mathrm{GABA}_{\mathrm{A}}$ Rs. If an increase in the number of postsynaptic receptors contributes to the enhancement in synaptic transmission at these synapses after MD, then quantal amplitude should also increase after MD. To selectively probe for changes in quantal 
amplitude at $\mathrm{FS} \rightarrow \mathrm{SP}$ synapses without activating other classes of GABAergic inputs, we expressed ChR2 in PVcontaining FS cells. We then recorded evoked quantal mIPSCs from postsynaptic L4 star pyramidal neurons in the presence of strontium to desynchronize release. To selectively express ChR2 in FS cells, we mated a line of mice expressing Cre-recombinase exclusively in PV-ir FS cells $\left(\mathrm{PV}^{\text {cre }}\right)$ to a line expressing a floxed STOP cassette upstream of an EYFPtagged ChR2 (ChR2 (H134R), Ai32 mice; Jackson Laboratories). At p26, mice heterozygous for the ChR2 allele (hereafter termed $\mathrm{ChPV}^{+/-}$mice) had nearly $100 \%$ overlap ( $99.3 \pm 0.72 \%, n=123$ cells from 2 animals) between the ChR2 EYFP-reporter and an anti-parvalbumin (PV) antibody within layer $4 \mathrm{~V} 1 \mathrm{~m}$ interneuron somata (Fig. $4 A, B$ ).

To examine the effects of brief MD on $\mathrm{FS} \rightarrow$ SP mIPSCs, we monocularly deprived $\mathrm{ChPV}^{+/-}$mice from $\mathrm{p} 22 / 3-\mathrm{p} 25 / 6$ and cut acute coronal slices containing V1m. We then stimulated FS cells with brief pulse trains from a $473 \mathrm{~nm}$ laser (Fig. 4D) while recording from L4 star pyramidal neurons; each pulse evoked a large inhibitory current followed by desynchronized individual mIPSCs (Fig. 4E). The frequency of these evoked mIPSCs was significantly elevated ( $\sim 3.5$-fold) over spontaneous mIPSC frequency (Fig. $4 F, G$ ). However, mIPSC rise time $(p=1.0)$, decay time $(p=0.1)$, and amplitude $(p=$ 0.5 ) were not significantly different between spontaneous and evoked events (Fig. $4 H-K$ ), suggesting that the evoked events were indeed quantal. This similarity between evoked and spontaneous mIPSCs also suggests that the majority of detectable spontaneous mIPSCs onto L4 star pyramidal neurons may arise from FS inputs.

Next, we compared the evoked mIPSCs from deprived and control hemispheres. There were no significant differences in evoked mIPSC frequency $(p=1.0)$, rise time $(p=0.8)$, or decay time $(p=0.3)$ between hemispheres (Fig. $5 B-E)$, or in pyramidal cell passive properties between conditions (deprived, $R_{\mathrm{in}}=83 \pm$ $15 \%, R_{\mathrm{s}}=96 \pm 4 \%$ of control values, $p=0.63$ and 0.37 , respectively). In contrast, evoked mIPSC amplitudes from deprived hemispheres were significantly larger $(\sim 53 \%)$ than in control hemispheres $(p=0.04 ; n=8$ cells/condition; Fig. $5 F-H)$. Cumulative amplitude histograms of mIPSC amplitude also showed a significant shift toward larger amplitude values $(p<0.001, \mathrm{KS}$ test; Fig. $5 G$ ). In sum, a relatively brief loss of patterned visual drive during the $\mathrm{CP}$ induces an increase in quantal amplitude at $\mathrm{FS} \rightarrow$ SP synapses.

\section{$\mathrm{GABA}_{\mathrm{A}} \mathrm{R}$ density at $\mathrm{FS} \rightarrow \mathrm{SP}$ synapses increases following MD during the $\mathrm{CP}$}

As there was no change in control versus deprived evoked mIPSC kinetics, we surmised the most likely explanation for an increase in mIPSC amplitude during the $\mathrm{CP}$ to be increased $\mathrm{GABA}_{\mathrm{A}} \mathrm{R}$ density at FS $\rightarrow$ SP synapses. To investigate this possibility, we again used
B
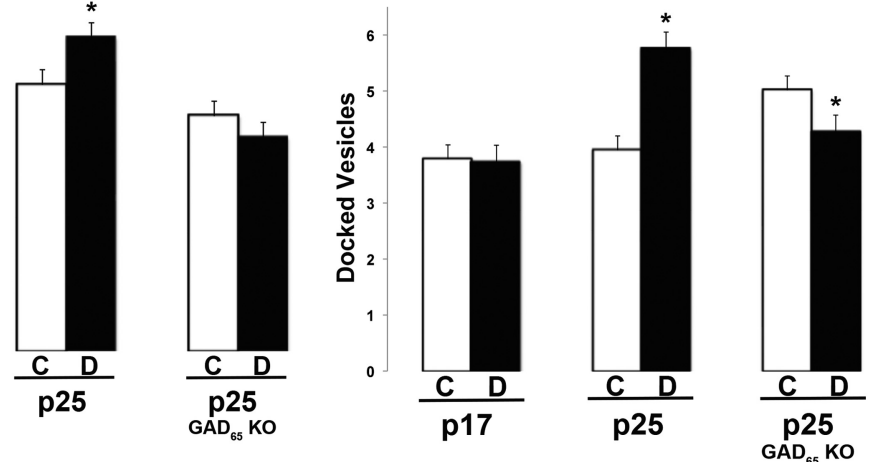

D

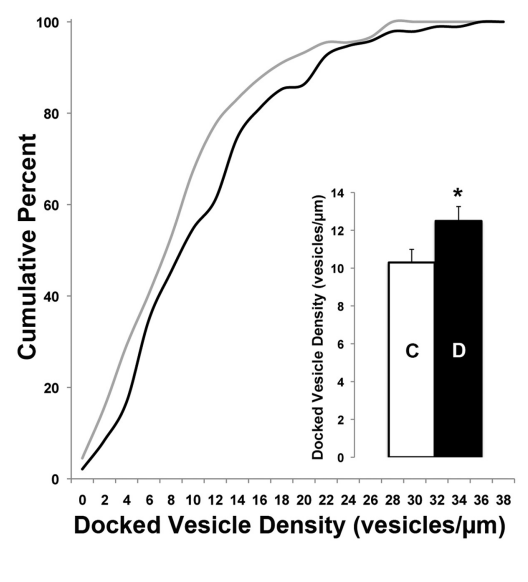

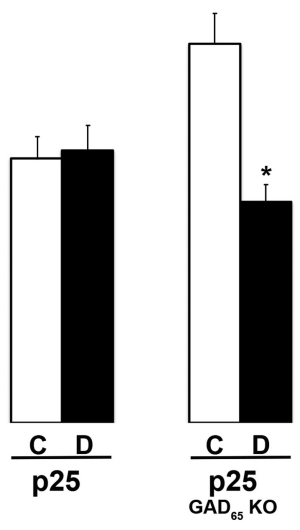

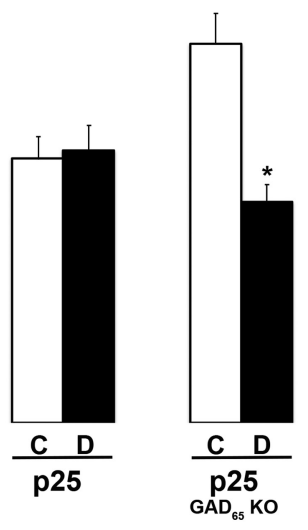

Figure 3. MD during the $C P$ increases FS presynaptic docked vesicle density. $\boldsymbol{A}$, Synapse sizes, as measured by mean postsynversus deprived hemispheres. $\boldsymbol{D}$, Cumulative percentage plot of docked vesicle density in control (gray line) and deprived (black line) hemispheres at $\mathrm{p} 25$. Inset shows data from cumulative histogram of average docked vesicle density. ${ }^{*} p<0.05$.

immunoelectron microscopy to locate and image FS $\rightarrow$ SP synapses, with the addition of a small gold label to visualize the $\gamma 2$-subunit of the $\mathrm{GABA}_{\mathrm{A}} \mathrm{R}$ (Fig. $6 A, B$ ). The $\gamma 2$-subunit is obligatory for clustering of $\mathrm{GABA}_{\mathrm{A}}$ Rs at inhibitory synapses, therefore this method allowed for the localization and analysis of $\mathrm{GABA}_{\mathrm{A}} \mathrm{R}$ density at FS perisomatic synapses (Essrich et al., 1998).

FS synapses in control and deprived hemispheres contained both presynaptic and postsynaptic $\mathrm{GABA}_{\mathrm{A}} \mathrm{R} \gamma 2$-subunits that tended to coalesce at the presynaptic and postsynaptic membranes (Fig. 6A, $B$ ), consistent with previous reports (Kullmann et al., 2005; Luscher et al., 2011). We first analyzed the axosomatic (presynaptic vs postsynaptic) distribution of goldlabeled $\gamma 2$-subunits at identified $\mathrm{FS} \rightarrow \mathrm{SP}$ synapses. If $\mathrm{MD}$ selectively increases postsynaptic $\mathrm{GABA}_{\mathrm{A}} \mathrm{R}$ density, one might expect a shift in the distribution of synaptic $\mathrm{GABA}_{\mathrm{A}}$ Rs toward the postsynaptic membrane. Indeed, MD induced a shift in the distribution of synaptic receptors toward the postsynaptic membrane compared with the distribution from the control hemispheres ( $p=0.02$, Wilcoxon; $p=0.003$, KS test; Fig. $6 C)$. In contrast, MD had no effect on the radial distribution of receptors along the length of the postsynaptic density ( $p=0.6$, Wilcoxon; $p=0.3$, KS test; Fig. $6 D$ ), indicating a relatively homogenous distribution of $\mathrm{GABA}_{\mathrm{A}} \mathrm{Rs}$ from the centroid to the lateral edge of the postsynaptic density at these synapses.

In addition to $\mathrm{GABA}_{\mathrm{A}} \mathrm{R}$ distribution, we quantified the density of $\mathrm{GABA}_{\mathrm{A}} \mathrm{R} \gamma 2$-subunits in both control and deprived $\mathrm{FS} \rightarrow \mathrm{SP}$ synapses. As before, pyramidal cells within layer 4 were 
A
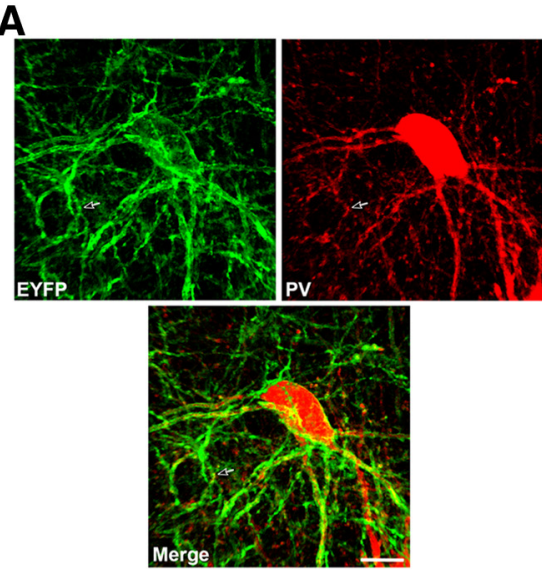

D

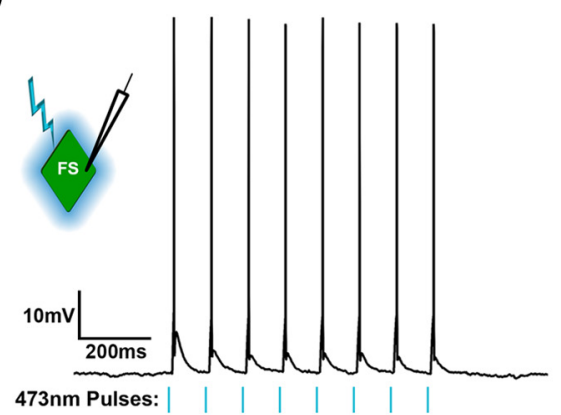

B
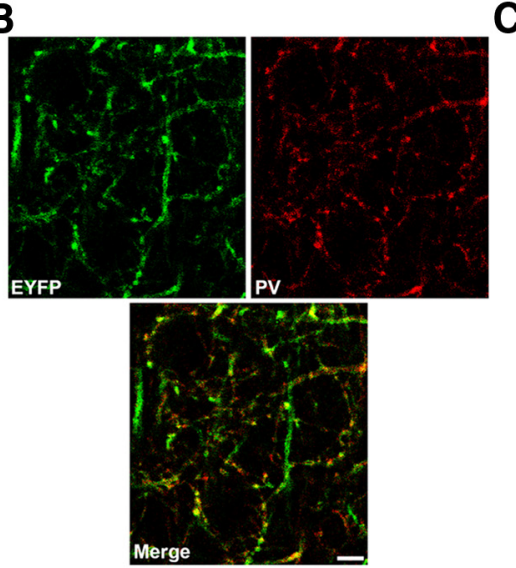

E

C

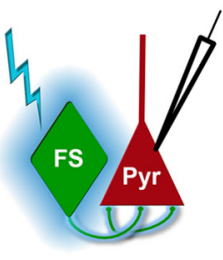

: $473 \mathrm{~nm}$ Pulse

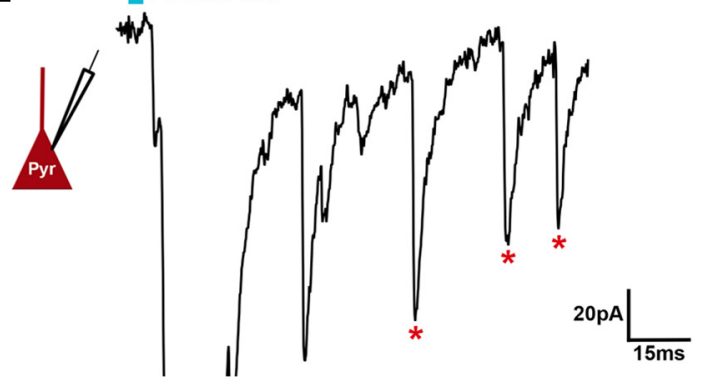

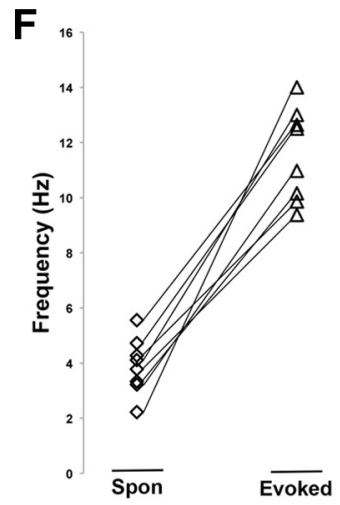

G

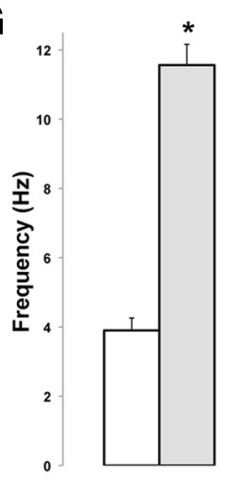

H

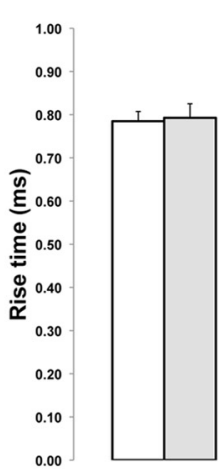

I

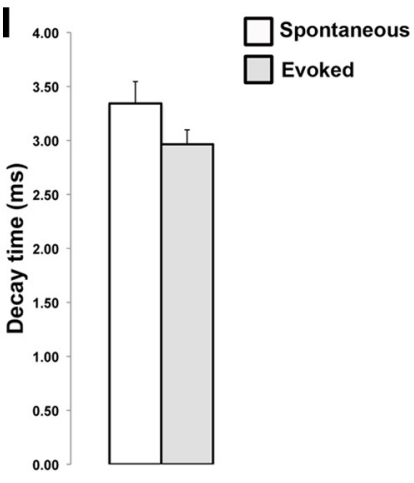

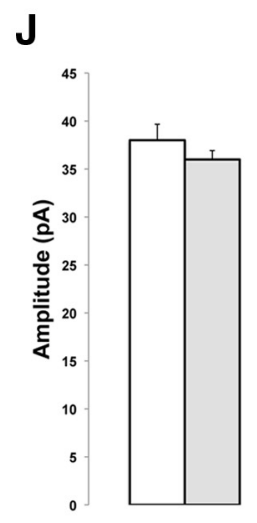

K

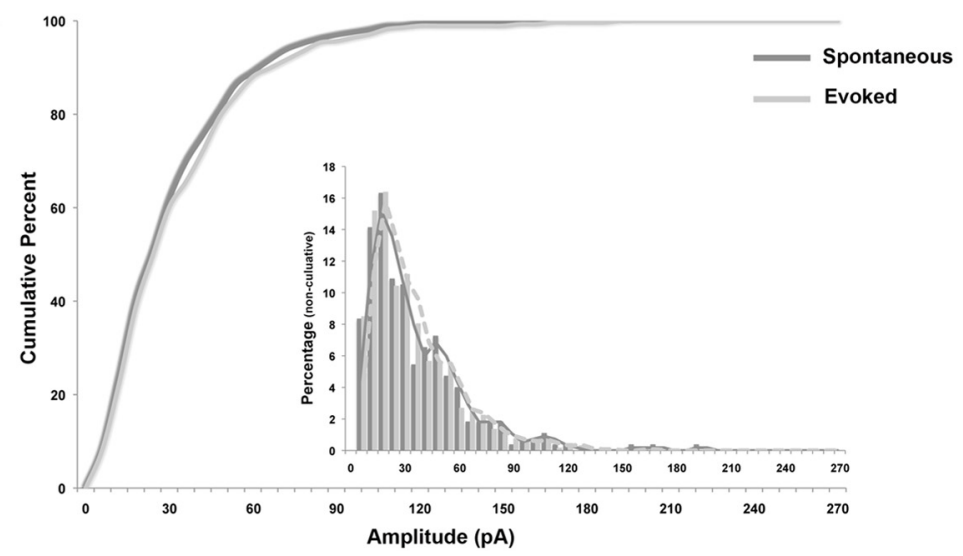

Figure 4. Evoked FS $\rightarrow$ SP mIPSCS. A, Collage of a three-dimensional projection from a confocal stack, showing a single FS interneuron double-labeled for EYFP-tagged ChR2 (green) and PV (red), and the merge of these two images. Arrow points to basket-like puncta. $\boldsymbol{B}$, Single optical section showing colocalization of EYFP and PV-ir labels in basket-like perisomatic puncta. C, Diagram of the experimental paradigm used for ChR2-evoked FS $\rightarrow$ SP mIPSC recordings. D, Representative trace showing evoked spikes in a FS interneuron following 5 ms laser pulses. $\boldsymbol{E}$, Representative trace of evoked mIPSCs (asterisks) recorded in strontium from a single star pyramidal neuron following a $5 \mathrm{~ms}$ laser pulse. Note that the large evoked inward current is followed by desynchronized and temporally separable mIPSCS. $\boldsymbol{F}$, Average spontaneous (diamonds) and evoked (triangles) mIPSC frequency from pyramidal cells in control hemispheres. G, Spontaneous and evoked mean mIPSC frequency from control hemispheres. $\boldsymbol{H}$, Spontaneous and evoked mean mIPSC $10-90 \%$ (Figure legend continues.) 
A

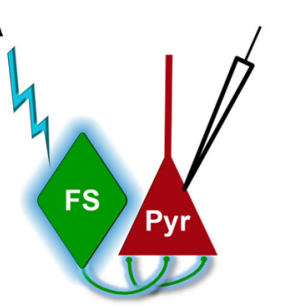

B

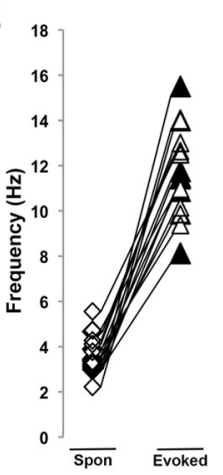

C

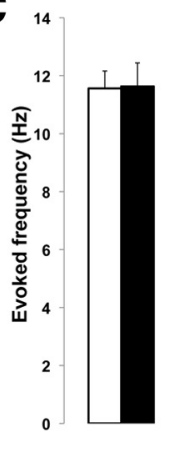

D

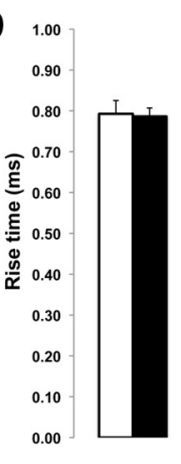

E

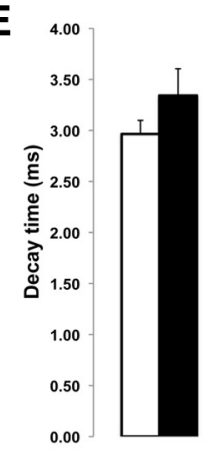

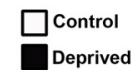

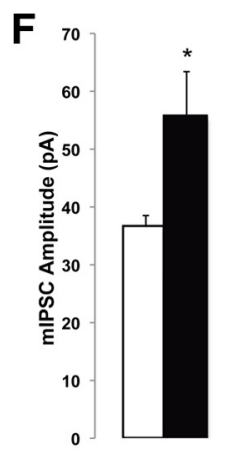

G
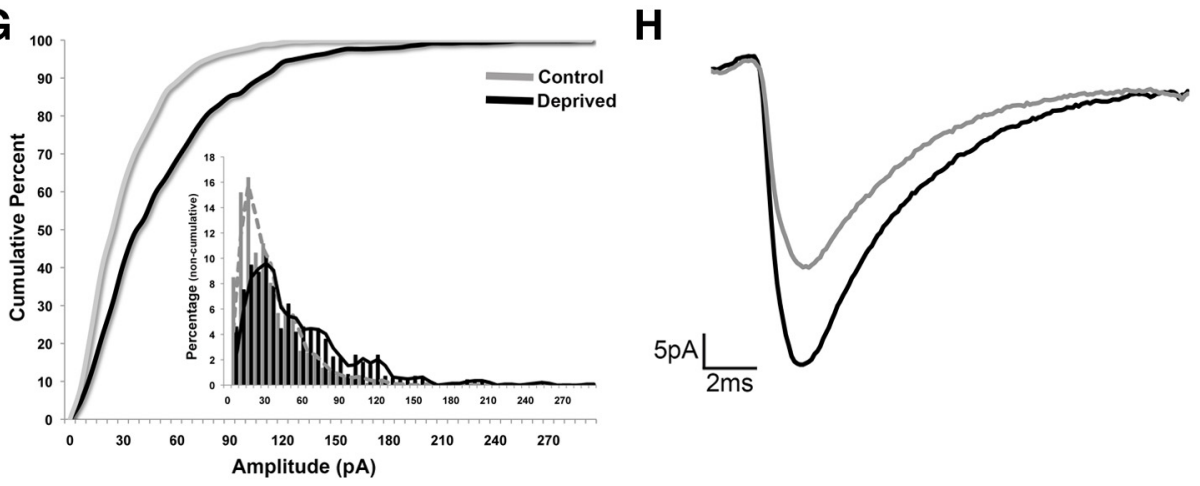

Figure 5. Evoked FS $\rightarrow$ SP mIPSC amplitude increases following MD during the CP. A, Diagram of the experimental paradigm used for ChR2-evoked FS $\rightarrow$ SP $\mathrm{mIPSC}$ recordings. $\boldsymbol{B}$, Average spontaneous (diamonds) and evoked (triangles) mIPSC frequency from pyramidal cells in control (white) and deprived (black) hemispheres. $\boldsymbol{C}$, Average mIPSC evoked frequency for control and deprived conditions. D, Average evoked mIPSC 10-90\% rise time for control and deprived hemispheres. $\boldsymbol{E}$, Average evoked mIPSC decay time for control and deprived hemispheres. $\boldsymbol{F}$, Average evoked mIPSC amplitude for control and deprived hemispheres. G, Cumulative percentage and histogram (inset) plots of evoked mIPSC amplitude in control and deprived hemispheres. Inset, Dotted and solid lines are running average fits with a period $=2$. $\boldsymbol{H}$, Average evoked mIPSC waveforms for control (gray) and deprived (black) hemispheres. ${ }^{*} p<0.05$.

chosen at random, and the number of $\gamma 2$-gold particles $40 \mathrm{~nm}$ presynaptic or postsynaptic from the center of the synaptic cleft were quantified at labeled PV-ir FS synapses. This distance was chosen based on the maximal distance that a membrane or postsynaptic density-bound gold label could extend into or away from the average-sized FS $\rightarrow$ SP synaptic cleft $(\sim 20 \mathrm{~nm})$, given the size of the primary and secondary antibodies coupled to a 5-7 $\mathrm{nm}$ gold particle ( $\sim 15-22 \mathrm{~nm})$ and thickness of the membrane/ postsynaptic density (5-7 nm; Werner et al., 1972; Hainfeld and Furuya, 1992; Harris et al., 1992). Presynaptic $\mathrm{GABA}_{\mathrm{A}} \mathrm{R} \gamma 2$ subunit density (number of gold particles $40 \mathrm{~nm}$ presynaptic from center of cleft/synapse length) was not significantly altered following $\mathrm{MD}(p=0.3$; Fig. $6 E)$. However, postsynaptic $\mathrm{GABA}_{\mathrm{A}} \mathrm{R} \gamma 2$-subunit density (number of gold particles $40 \mathrm{~nm}$ postsynaptic from center of cleft/synapse length) was significantly increased at $\mathrm{FS} \rightarrow \mathrm{SP}$ synapses of deprived hemispheres after MD ( $p=0.02$; Fig. $6 F)$. Hence, brief MD beginning at the cusp of the canonical CP results in increased $\mathrm{FS} \rightarrow \mathrm{SP}$ quantal amplitude and a commensurate increase in postsynaptic $\mathrm{GABA}_{\mathrm{A}}$ Rs.

\section{Discussion}

Tight regulation of FS inhibition is critical in shaping cortical response properties, generating cortical rhythms, and modulat-

(Figure legend continued.) rise time in control hemispheres. I, Spontaneous and evoked mean mIPSC decay time in control hemispheres. $J$, Spontaneous and evoked mean mIPSC amplitude in control hemispheres. $\boldsymbol{K}$, Cumulative percentage and histogram (inset) plots of spontaneous and evoked mIPSC amplitude in control hemispheres. Inset, Dotted and solid lines are running average fits with a period $=2$. Scale bars: $\boldsymbol{A}, 10 \mu \mathrm{m} ; \boldsymbol{B}, 5 \mu \mathrm{m} .{ }^{*} p<0.05$. ing cortical sensory maps (Huang et al., 1999; Gabernet et al., 2005; de la Rocha et al., 2008; Sohal et al., 2009; House et al., 2011; Lee et al., 2012). Experience-dependent plasticity of FS synapses contributes to this regulation, but the expression mechanisms that tune FS synaptic strength are poorly understood. Here we show that MD-induced FS $\rightarrow$ SP inhibitory plasticity in layer 4 is expressed through a coordinated set of presynaptic and postsynaptic changes that increase both the density of presynaptic release sites and the density of postsynaptic $\mathrm{GABA}_{\mathrm{A}}$ receptors. These changes are specific to $\mathrm{MD}$-induced plasticity during the $\mathrm{CP}$, and are prevented by a mutation $\left(\mathrm{GAD}_{65} \mathrm{KO}\right)$ that prevents $\mathrm{CP}$ onset, suggesting that this form of FS plasticity is tightly coupled to the onset of the canonical visual system CP.

Several distinct forms of neocortical FS synaptic plasticity have been described, including whisker deprivation-induced potentiation at $\mathrm{FS} \rightarrow$ SP synapses in L2/3 barrel cortex (House et al., 2011), potentiation of FS $\rightarrow$ FS synapses in L2/3 of V1 (Sarihi et al., 2012), spike timing-dependent plasticity at FS $\rightarrow$ SP synapses in L2/3 (Holmgren and Zilberter, 2001; Liu et al., 2007), and developmentally regulated potentiation and depression at FS $\rightarrow$ SP synapses in V1 L4 (Maffei et al., 2006; Lefort et al., 2013). Plasticity of FS synapses is thus a robust feature of primary sensory neocortex, yet the expression mechanisms of these various forms of FS plasticity remain largely unexplored.

One potential locus of FS plasticity is changes in the number of functional FS presynaptic terminals. FS bouton density onto pyramidal neurons is developmentally regulated: observed terminal density increased between p15 and p17 and then stabilized between $\mathrm{p} 17$ and $\mathrm{p} 25$. In addition to this developmental regulation, prolonged sensory deprivation ( $>14 \mathrm{~d}$ ) reduces FS bouton number in both visual and barrel cortex (Cellerino et al., 1992; Jiao et 
A

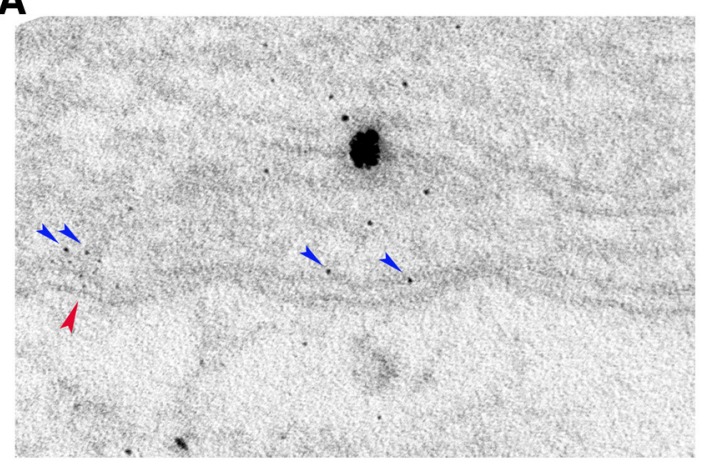

\section{C}
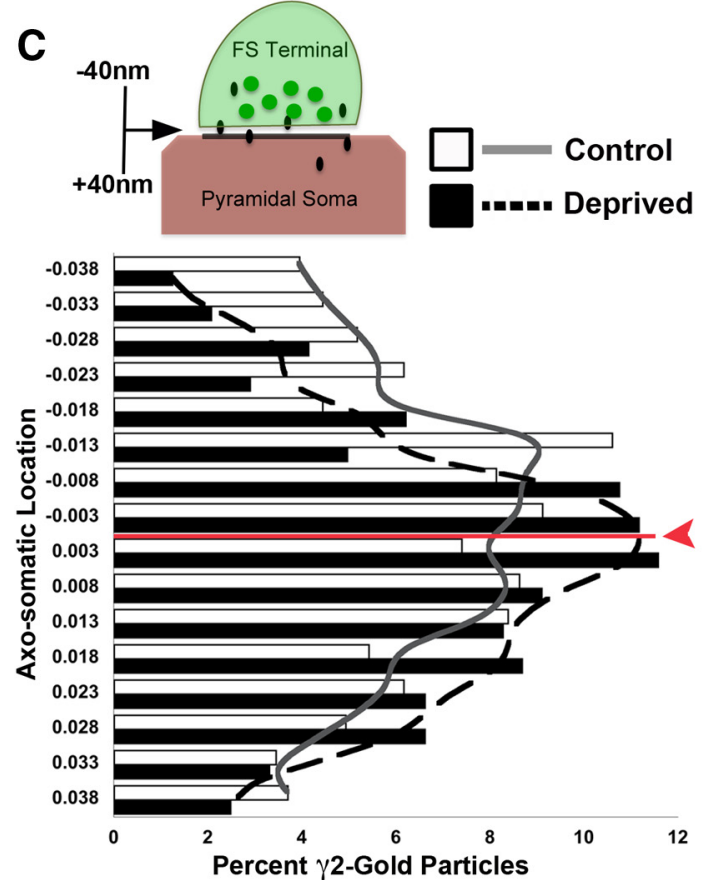

E

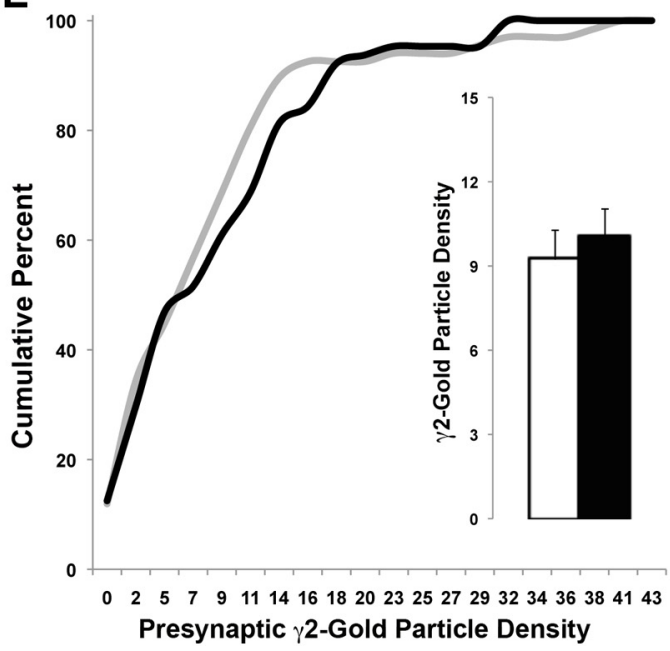

B

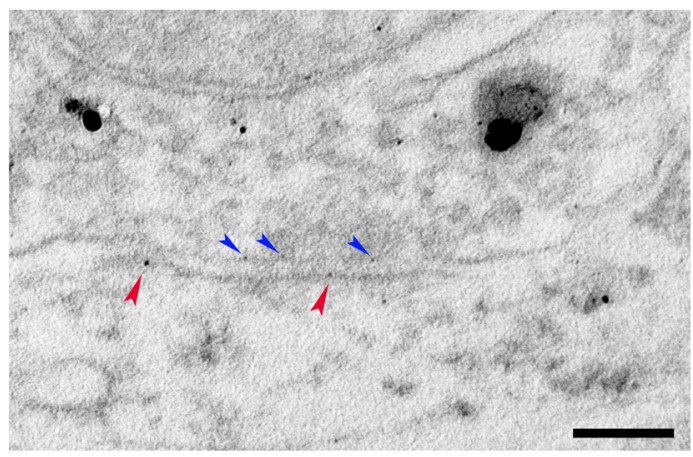

D
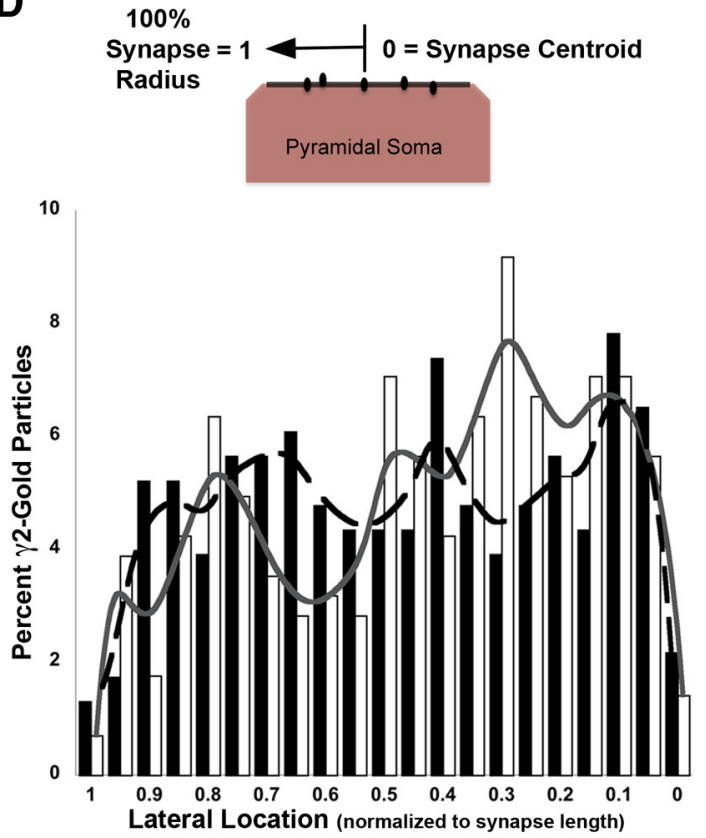

$\mathbf{F}$

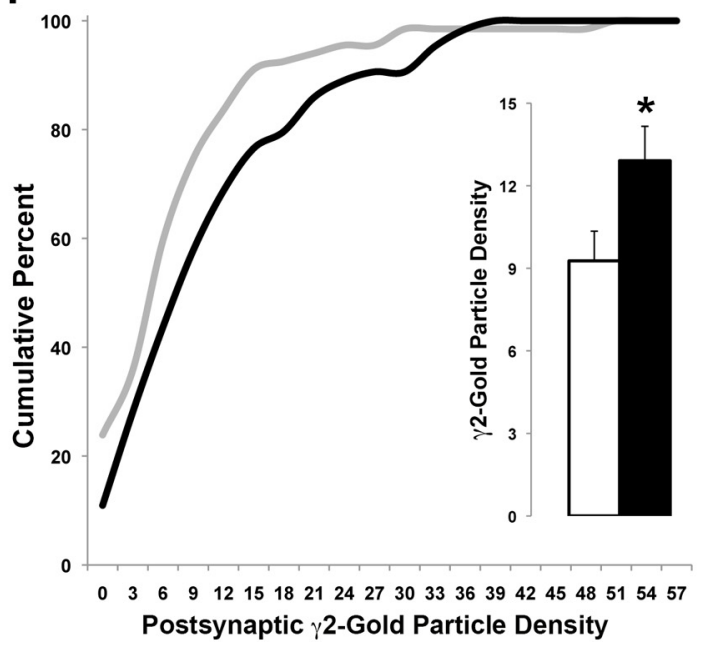

Figure 6. $\quad G_{A B A} R$ density at $\mathrm{FS} \rightarrow S P$ synapses increases following MD during the (P. A, Representative image of a $F S \rightarrow S P$ synapse from a p25 control hemisphere showing preembedding labeling for PV (large silver-enhanced gold particles) and postembedding labeling for presynaptic (blue arrowheads) and postsynaptic (red arrowheads) $\mathrm{GABA}_{\mathrm{A}} \gamma 2$-subunits (5 nm gold particles). $B, G A B A_{A} R s$ at a p25 FS $\rightarrow$ SP synapse from a deprived hemisphere. C, Axo-somatic (presynaptic vs postsynaptic) distribution of $G_{A B A_{A}} \gamma 2$-gold labeling in control and deprived hemispheres. Red line and arrowhead indicate centroid of synaptic cleft. Dotted and solid lines are running average fits with a period $=2$. D, Radial distribution (normalized to synapse length) of $\mathrm{GABA}_{A} \gamma 2$-gold labeling in control and deprived hemispheres. $\boldsymbol{E}$, Cumulative percentage histogram and average bar plot (inset) for presynaptic GABA $A_{A} \gamma 2$-gold particle density (see Materials and Methods, and Results). $\boldsymbol{F}$, Cumulative percentage histogram and average bar plot (inset) for postsynaptic $\mathrm{GABA}_{\mathrm{A}} \gamma 2$-gold particle density. Scale bar: (in $\left.\boldsymbol{B}\right) \boldsymbol{A}, \boldsymbol{B}, 100 \mathrm{~nm}$. ${ }^{*} p<0.05$. 
al., 2006). In contrast, we found that brief MD did not modulate $\mathrm{FS} \rightarrow$ SP synaptic strength through changes in bouton number. Indeed, even deprivation during the pre-CP (when bouton number is still developmentally plastic) did not result in significant deprivation-induced changes. Thus, the relatively rapid forms of FS plasticity induced by brief MD are not accomplished through changes in bouton number.

To carefully examine the locus of plasticity at existing boutons, we used a combined ultrastructural and optogenetic approach. MD depresses FS $\rightarrow$ SP transmission during the pre-CP but potentiates it during the CP (Maffei et al., 2004, 2006, 2010). We found that brief MD during the $\mathrm{CP}$ increased both the length of the active zone and the density of docked vesicles, and this was accompanied by an increase in the density of postsynaptic $\mathrm{GABA}_{\mathrm{A}}$ Rs. These findings suggest that potentiation at this synapse arises jointly from an increase in the number of functional release sites per bouton and an increase in the effectiveness of each released quantum of neurotransmitter. Assuming a standard binomial model of synaptic transmission (Faber and Korn, 1991; Larkman et al., 1992; Sjöström et al., 2007), these changes are predicted to enhance synaptic strength and reduce synaptic variance, through an increase in the number of functional release sites $(\mathrm{N})$, without affecting the short-term dynamics of transmission, as previously observed (Maffei et al., 2006). Indeed, if the number of docked vesicles is a direct measure of N, the MDinduced increase we observed (Fig. $3 B, D$ ) is predicted to reduce the CV by $\sim 20 \%$ (Faber and Korn, 1991). This is very close to the actual MD-induced reduction in CV measured at this synapse ( $\sim 25 \%$; Maffei and Turrigiano, 2008), suggesting that the increase in docked vesicles accounts for most of the reduction in measured CV. Given that short-term synaptic dynamics at inhibitory synapses contribute to the maintenance of the excitationinhibition balance (Varela et al., 1999; Reyes, 2011; Ma et al., 2012), targeting $N$ (rather than probability of release) may be an efficient way of modulating FS synaptic strength without destabilizing circuit dynamics.

It has been suggested that there is a synaptic "size principle" in which larger synapses are stronger (Henneman, 1957; Pierce and Lewin, 1994). Synapse size and strength tend to be correlated (Desmond and Levy, 1983; Murthy et al., 2001; Branco et al., 2010; Holderith et al., 2012), and LTP and LTD induction at excitatory synapses can be associated with synapse growth and shrinkage, respectively (Yuste and Bonhoeffer, 2001; Ostroff et al., 2002; Matsuzaki et al., 2004; Zhou et al., 2004). Conversely, the physiological and anatomical plasticity following LTP can be dissociated (Wang et al., 2007; Bosch and Hayashi, 2012; Hill and Zito, 2013), suggesting that the factors that regulate size and strength are separable. Here we find that while MD during the $\mathrm{CP}$ increases FS synapse size, the number of docked vesicles and postsynaptic receptors increases to an even greater degree, such that the density of docked vesicles and postsynaptic receptors is significantly increased. Therefore, the MD-induced increase in FS synaptic output is not merely the consequence of increased synapse size but must involve active mechanisms that adjust the density of both presynaptic and postsynaptic components of transmission.

This coordinated increase in presynaptic and postsynaptic aspects of synaptic transmission has implications for the induction mechanisms of this form of FS plasticity. In particular, it suggests that there is some form of trans-synaptic signaling, beyond simple size coupling, which leads to coordinated presynaptic and postsynaptic strengthening. There is evidence that the MDinduced potentiation of FS $\rightarrow$ SP transmission arises through the induction of a form of LTP of inhibition (LTPi) induced by decorrelated visual drive (Maffei et al., 2006), whereas the depression of $\mathrm{FS} \rightarrow \mathrm{SP}$ transmission induced during the pre-CP is correlated with the expression of LTP of inhibition (LTDi) at this same synapse (Lefort et al., 2013). Both LTPi and LTDi require postsynaptic depolarization and signaling through $\mathrm{GABA}_{\mathrm{B}}$ Rs (Lefort et al., 2013), but it is currently unknown whether this requirement for $\mathrm{GABA}_{\mathrm{B}} \mathrm{R}$ signaling is mediated through presynaptic or postsynaptic receptors. Another interesting possibility is that this plasticity could require signaling through a retrograde signal, such as BDNF, which has been implicated in many aspects of FS cell development, as well as in the activity-dependent strengthening of FS inhibition (Huang et al., 1999; Itami et al., 2007; Inagaki et al., 2008).

There is accumulating evidence that FS interneurons are permissive for the initiation phase of the classical CP in rodent V1 (Huang et al., 1999; Fagiolini and Hensch, 2000; Pizzorusso et al., 2002; Southwell et al., 2010), yet it remains unclear which aspects of FS circuit maturation are essential for the initiation and maintenance of CP plasticity. Two recent papers (Hengen et al., 2013; Kuhlman et al., 2013) provide evidence that a rapid drop in FS activity after $1 \mathrm{~d}$ of MD, followed by a homeostatic rebound in FS activity by day 2 of $\mathrm{MD}$, may gate the initial stages of CP plasticity in V1m and V1b. Coupled with the observation that FS plasticity changes sign ( - to + ) at the opening of the CP (Maffei et al., 2004, 2006; Lefort et al., 2013), these data raise the possibility that potentiation at this synapse contributes to the gating of CP plasticity within L4.

In support of this idea, here we find that $\mathrm{GAD}_{65} \mathrm{KO}$ mice that are unable to initiate CP plasticity in V1 (Hensch et al., 1998; Fagiolini and Hensch, 2000; Iwai et al., 2003) also fail to show the morphological correlates of potentiation at FS $\rightarrow$ SP synapses following brief MD. Interestingly, there were significant baseline morphological differences at $\mathrm{FS} \rightarrow \mathrm{SP}$ synapses between the $\mathrm{GAD}_{65} \mathrm{KO}$ mice and controls, including a larger readily releasable pool and an increase in docked vesicles (Fig. $3 B, C$ ). These baseline changes in $\mathrm{GAD}_{65} \mathrm{KO}$ mice may reflect homeostatic alterations of morphology designed to compensate for the loss of vesicular GABAergic content, similar to the reported increase in GABA uptake efficiency within $\mathrm{GAD}_{65} \mathrm{KO}$ synaptic vesicles ( $\mathrm{Wu}$ et al., 2007). Further, rather than simply lacking plasticity, the $\mathrm{GAD}_{65} \mathrm{KO}$ mice underwent a reduction (rather than increase) in the number of docked vesicles at FS synapses after MD, suggesting that both baseline transmission and plasticity at FS synapses have been fundamentally altered in these mice.

A building consensus suggests that potentiation and depression of the FS $\rightarrow$ SP synapse is an integral feature of mammalian circuit development and refinement in sensory cortex (Castillo et al., 2011; Maffei, 2011; Vogels et al., 2013). GABAergic inhibition plays a crucial role in shaping cortical response properties in V1 (Atallah et al., 2012; Lee et al., 2012; Wilson et al., 2012), suggesting that plasticity of FS output during normal vision could play an important role in the refinement of visual cortical response properties. Here we demonstrate that experience-dependent changes in FS $\rightarrow$ SP synaptic strength are coincidently expressed both presynaptically and postsynaptically during a developmental window of heightened malleability in V1. These coordinated changes in FS output may represent an expression pathway for modulating sensory tuning, as well as a necessary step in gating $\mathrm{MD}$-induced pyramidal cell plasticity during the $\mathrm{CP}$ in visual cortex. 


\section{References}

Atallah BV, Bruns W, Carandini M, Scanziani M (2012) Parvalbuminexpressing interneurons linearly transform cortical responses to visual stimuli. Neuron 73:159-170. CrossRef Medline

Bosch M, Hayashi Y (2012) Structural plasticity of dendritic spines. Curr Opin Neurobiol 22:383-388. CrossRef Medline

Branco T, Marra V, Staras K (2010) Examining size-strength relationships at hippocampal synapses using an ultrastructural measurement of synaptic release probability. J Struct Biol 172:203-210. CrossRef Medline

Castillo PE, Chiu CQ, Carroll RC (2011) Long-term plasticity at inhibitory synapses. Curr Opin Neurobiol 21:328-338. CrossRef Medline

Cellerino A, Siciliano R, Domenici L, Maffei L (1992) Parvalbumin immunoreactivity: a reliable marker for the effects of monocular deprivation in the rat visual cortex. Neuroscience 51:749-753. CrossRef Medline

Chattopadhyaya B, Di Cristo G, Higashiyama H, Knott GW, Kuhlman SJ, Welker E, Huang ZJ (2004) Experience and activity-dependent maturation of perisomatic GABAergic innervation in primary visual cortex during a postnatal critical period. J Neurosci 24:9598-9611. CrossRef Medline

Coleman JE, Nahmani M, Gavornik JP, Haslinger R, Heynen AJ, Erisir A, Bear MF (2010) Rapid structural remodeling of thalamocortical synapses parallels experience-dependent functional plasticity in mouse primary visual cortex. J Neurosci 30:9670-9682. CrossRef Medline

Czeiger D, WhiteEL (1997) Comparison of the distribution of parvalbuminimmunoreactive and other synapses onto the somata of callosal projection neurons in mouse visual and somatosensory cortex. J Comp Neurol 379:198-210. CrossRef Medline

Darcy KJ, Staras K, Collinson LM, Goda Y (2006) Constitutive sharing of recycling synaptic vesicles between presynaptic boutons. Nat Neurosci 9:315-321. CrossRef Medline

de la Rocha J, Marchetti C, Schiff M, Reyes AD (2008) Linking the response properties of cells in auditory cortex with network architecture: cotuning versus lateral inhibition. J Neurosci 28:9151-9163. CrossRef Medline

DeFelipe J, Fairén A (1982) A type of basket cell in superficial layers of the cat visual cortex. A Golgi-electron microscope study. Brain Res 244:9-16. CrossRef Medline

Desmond NL, Levy WB (1983) Synaptic correlates of associative potentiation/depression: an ultrastructural study in the hippocampus. Brain Res 265:21-30. CrossRef Medline

Essrich C, Lorez M, Benson JA, Fritschy JM, Lüscher B (1998) Postsynaptic clustering of major GABAA receptor subtypes requires the $\gamma 2$ subunit and gephyrin. Nat Neurosci 1:563-571. CrossRef Medline

Faber DS, Korn H (1991) Applicability of the coefficient of variation method for analyzing synaptic plasticity. Biophys J 60:1288-1294. CrossRef Medline

Fagiolini M, Hensch TK (2000) Inhibitory threshold for critical-period activation in primary visual cortex. Nature 404:183-186. CrossRef Medline

Fernández-Busnadiego R, Zuber B, Maurer UE, Cyrklaff M, Baumeister W, Lucic V (2010) Quantitative analysis of the native presynaptic cytomatrix by cryoelectron tomography. J Cell Biol 188:145-156. CrossRef Medline

Fiala JC (2005) Reconstruct: a free editor for serial section microscopy. J Microsc 218:52-61. CrossRef Medline

Gabernet L, Jadhav SP, Feldman DE, Carandini M, Scanziani M (2005) Somatosensory integration controlled by dynamic thalamocortical feedforward inhibition. Neuron 48:315-327. CrossRef Medline

Hainfeld JF, Furuya FR (1992) A 1.4-nm gold cluster covalently attached to antibodies improves immunolabeling. J Histochem Cytochem 40:177184. CrossRef Medline

Harris KM, Fiala JC, Ostroff L (2003) Structural changes at dendritic spine synapses during long-term potentiation. Philos Trans R Soc Lond B Biol Sci 358:745-748. CrossRef Medline

Harris KM, Perry E, Bourne J, Feinberg M, Ostroff L, Hurlburt J (2006) Uniform serial sectioning for transmission electron microscopy. J Neurosci 26:12101-12103. CrossRef Medline

Harris LJ, Larson SB, Hasel KW, Day J, Greenwood A, McPherson A (1992) The three-dimensional structure of an intact monoclonal antibody for canine lymphoma. Nature 360:369-372. CrossRef Medline

Hengen KB, Lambo ME, Van Hooser SD, Katz DB, Turrigiano GG (2013) Firing rate homeostasis in visual cortex of freely behaving rodents. Neuron 80:335-342. CrossRef Medline

Henneman E (1957) Relation between size of neurons and their susceptibility to discharge. Science 126:1345-1347. CrossRef Medline
Hensch TK, Fagiolini M, Mataga N, Stryker MP, Baekkeskov S, Kash SF (1998) Local GABA circuit control of experience-dependent plasticity in developing visual cortex. Science 282:1504-1508. CrossRef Medline

Hill TC, Zito K (2013) LTP-induced long-term stabilization of individual nascent dendritic spines. J Neurosci 33:678-686. CrossRef Medline

Hippenmeyer S, Vrieseling E, Sigrist M, Portmann T, Laengle C, Ladle DR, Arber S (2005) A developmental switch in the response of DRG neurons to ETS transcription factor signaling. PLoS Biol 3:e159. CrossRef Medline

Holderith N, Lorincz A, Katona G, Rózsa B, Kulik A, Watanabe M, Nusser Z (2012) Release probability of hippocampal glutamatergic terminals scales with the size of the active zone. Nat Neurosci 15:988-997. CrossRef Medline

Holländer H, Vanegas H (1981) Identification of pericellular baskets in the cat striate cortex: light and electron microscopic observations after uptake of horseradish peroxidase. J Neurocytol 10:577-587. CrossRef Medline

Holmgren CD, Zilberter Y (2001) Coincident spiking activity induces longterm changes in inhibition of neocortical pyramidal cells. J Neurosci 21: 8270-8277. Medline

House DR, Elstrott J, Koh E, Chung J, Feldman DE (2011) Parallel regulation of feedforward inhibition and excitation during whisker map plasticity. Neuron 72:819-831. CrossRef Medline

Huang ZJ, Kirkwood A, Pizzorusso T, Porciatti V, Morales B, Bear MF, Maffei L, Tonegawa S (1999) BDNF regulates the maturation of inhibition and the critical period of plasticity in mouse visual cortex. Cell 98:739-755. CrossRef Medline

Inagaki T, Begum T, Reza F, Horibe S, Inaba M, Yoshimura Y, Komatsu Y (2008) Brain-derived neurotrophic factor-mediated retrograde signaling required for the induction of long-term potentiation at inhibitory synapses of visual cortical pyramidal neurons. Neurosci Res 61:192-200. CrossRef Medline

Itami C, Kimura F, Nakamura S (2007) Brain-derived neurotrophic factor regulates the maturation of layer 4 fast-spiking cells after the second postnatal week in the developing barrel cortex. J Neurosci 27:2241-2252. CrossRef Medline

Iwai Y, Fagiolini M, Obata K, Hensch TK (2003) Rapid critical period induction by tonic inhibition in visual cortex. J Neurosci 23:6695-6702. Medline

Jiang B, Sohya K, Sarihi A, Yanagawa Y, Tsumoto T (2010) Laminar-specific maturation of GABAergic transmission and susceptibility to visual deprivation are related to endocannabinoid sensitivity in mouse visual cortex. J Neurosci 30:14261-14272. CrossRef Medline

Jiao Y, Zhang C, Yanagawa Y, Sun QQ (2006) Major effects of sensory experiences on the neocortical inhibitory circuits. J Neurosci 26:8691-8701. CrossRef Medline

Kuhlman SJ, Olivas ND, Tring E, Ikrar T, Xu X, Trachtenberg JT (2013) A disinhibitory microcircuit initiates critical-period plasticity in the visual cortex. Nature 501:543-546. CrossRef Medline

Kullmann DM, Ruiz A, Rusakov DM, Scott R, Semyanov A, Walker MC (2005) Presynaptic, extrasynaptic and axonal GABAA receptors in the CNS: where and why? Prog Biophys Mol Biol 87:33-46. CrossRef Medline

Lamsa KP, Kullmann DM, Woodin MA (2010) Spike-timing-dependent plasticity in inhibitory circuits. Front Synaptic Neurosci 2:8. Medline

Larkman A, Hannay T, Stratford K, Jack J (1992) Presynaptic release probability influences the locus of long-term potentiation. Nature 360:70-73. CrossRef Medline

Lazarus MS, Huang ZJ (2011) Distinct maturation profiles of perisomatic and dendritic targeting GABAergic interneurons in the mouse primary visual cortex during the critical period for ocular dominance plasticity. J Neurophysiol 106:775-787. CrossRef Medline

Lee SH, Kwan AC, Zhang S, Phoumthipphavong V, Flannery JG, Masmanidis SC, Taniguchi H, Huang ZJ, Zhang F, Boyden ES, Deisseroth K, Dan Y (2012) Activation of specific interneurons improves V1 feature selectivity and visual perception. Nature 488:379-383. CrossRef Medline

Lefort S, Gray AC, Turrigiano GG (2013) Long-term inhibitory plasticity in visual cortical layer 4 switches sign at the opening of the critical period. Proc Natl Acad Sci U S A 110:E4540-4547. CrossRef Medline

Liu Y, Zhang LI, Tao HW (2007) Heterosynaptic scaling of developing GABAergic synapses: dependence on glutamatergic input and developmental stage. J Neurosci 27:5301-5312. CrossRef Medline

Luscher B, Fuchs T, Kilpatrick CL (2011) GABAA receptor traffickingmediated plasticity of inhibitory synapses. Neuron 70:385-409. CrossRef Medline 
Ma Y, Hu H, Agmon A (2012) Short-term plasticity of unitary inhibitoryto-inhibitory synapses depends on the presynaptic interneuron subtype. J Neurosci 32:983-988. CrossRef Medline

Maffei A (2011) The many forms and functions of long term plasticity at GABAergic synapses. Neural Plast 2011:254724. CrossRef Medline

Maffei A, Turrigiano G (2008) The age of plasticity: Developmental regulation of synaptic plasticity in neocortical microcircuits. Prog Brain Res 169:211-223. CrossRef Medline

Maffei A, Nelson SB, Turrigiano GG (2004) Selective reconfiguration of layer 4 visual cortical circuitry by visual deprivation. Nat Neurosci 7:1353-1359. CrossRef Medline

Maffei A, Nataraj K, Nelson SB, Turrigiano GG (2006) Potentiation of cortical inhibition by visual deprivation. Nature 443:81-84. CrossRef Medline

Maffei A, Lambo ME, Turrigiano GG (2010) Critical period for inhibitory plasticity in rodent binocular V1. J Neurosci 30:3304-3309. CrossRef Medline

Matsuzaki M, Honkura N, Ellis-Davies GCR, Kasai H (2004) Structural basis of long-term potentiation in single dendritic spines. Nature 429:761766. CrossRef Medline

Murthy VN, Schikorski T, Stevens CF, Zhu Y (2001) Inactivity produces increases in neurotransmitter release and synapse size. Neuron 32:673682. CrossRef Medline

Nahmani M, Erisir A (2005) VGluT2 immunochemistry identifies thalamocortical terminals in layer 4 of adult and developing visual cortex. J Comp Neurol 484:458-473. CrossRef Medline

Okaty BW, Miller MN, Sugino K, Hempel CM, Nelson SB (2009) Transcriptional and electrophysiological maturation of neocortical fastspiking GABAergic interneurons. J Neurosci 29:7040-7052. CrossRef Medline

Ostroff LE, Fiala JC, Allwardt B, Harris KM (2002) Polyribosomes redistribute from dendritic shafts into spines with enlarged synapses during LTP in developing rat hippocampal slices. Neuron 35:535-545. CrossRef Medline

Pangratz-Fuehrer S, Hestrin S (2011) Synaptogenesis of electrical and GABAergic synapses of fast-spiking inhibitory neurons in the neocortex. J Neurosci 31:10767-10775. CrossRef Medline

Pierce JP, Lewin GR (1994) An ultrastructural size principle. Neuroscience 58:441-446. CrossRef Medline

Pizzorusso T, Medini P, Berardi N, Chierzi S, Fawcett JW, Maffei L (2002) Reactivation of ocular dominance plasticity in the adult visual cortex. Science 298:1248-1251. CrossRef Medline

Reyes AD (2011) Synaptic short-term plasticity in auditory cortical circuits. Hear Res 279:60-66. CrossRef Medline

Rutledge LT (1978) The effects of denervation and stimulation upon synaptic ultrastructure. J Comp Neurol 178:117-128. CrossRef Medline

Sarihi A, Mirnajafi-Zadeh J, Jiang B, Sohya K, Safari MS, Arami MK, Yanagawa Y, Tsumoto T (2012) Cell type-specific, presynaptic LTP of inhibitory synapses on fast-spiking GABAergic neurons in the mouse visual cortex. J Neurosci 32:13189-13199. CrossRef Medline
Schneider CA, Rasband WS, Eliceiri KW (2012) NIH Image to ImageJ: 25 years of image analysis. Nat Methods 9:671-675. CrossRef Medline

Siksou L, Triller A, Marty S (2011) Ultrastructural organization of presynaptic terminals. Curr Opin Neurobiol 21:261-268. CrossRef Medline

Sjöström PJ, Turrigiano GG, Nelson SB (2007) Multiple forms of long-term plasticity at unitary neocortical layer 5 synapses. Neuropharmacology 52:176-184. CrossRef Medline

Sohal VS, Zhang F, Yizhar O, Deisseroth K (2009) Parvalbumin neurons and gamma rhythms enhance cortical circuit performance. Nature 459: 698-702. CrossRef Medline

Somogyi P, Kisvárday ZF, Martin KA, Whitteridge D (1983) Synaptic connections of morphologically identified and physiologically characterized large basket cells in the striate cortex of cat. Neuroscience 10:261-294. CrossRef Medline

Southwell DG, Froemke RC, Alvarez-Buylla A, Stryker MP, Gandhi SP (2010) Cortical plasticity induced by inhibitory neuron transplantation. Science 327:1145-1148. CrossRef Medline

Varela JA, Song S, Turrigiano GG, Nelson SB (1999) Differential depression at excitatory and inhibitory synapses in visual cortex. J Neurosci 19:42934304. Medline

Vogels TP, Froemke RC, Doyon N, Gilson M, Haas JS, Liu R, Maffei A, Miller P, Wierenga CJ, Woodin MA, Zenke F, Sprekeler H (2013) Inhibitory synaptic plasticity: spike timing-dependence and putative network function. Front Neural Circuits 7:119. Medline

Wang XB, Yang Y, Zhou Q (2007) Independent expression of synaptic and morphological plasticity associated with long-term depression. J Neurosci 27:12419-12429. CrossRef Medline

Werner TC, Bunting JR, Cathou RE (1972) The shape of immunoglobulin G molecules in solution. Proc Natl Acad Sci U S A 69:795-799. CrossRef Medline

Whittington MA, Traub RD, Jefferys JGR (1995) Synchronized oscillations in interneuron networks driven by metabotropic glutamate receptor activation. Nature 373:612-615. CrossRef Medline

Wilson NR, Runyan CA, Wang FL, Sur M (2012) Division and subtraction by distinct cortical inhibitory networks in vivo. Nature 488:343-348. CrossRef Medline

Wu H, Jin Y, Buddhala C, Osterhaus G, Cohen E, Jin H, Wei J, Davis K, Obata $\mathrm{K}$, Wu JY (2007) Role of glutamate decarboxylase (GAD) isoform, GAD65, in GABA synthesis and transport into synaptic vesicles: evidence from GAD65-knockout mice studies. Brain Res 1154:80-83. CrossRef Medline

Yazaki-Sugiyama Y, Kang S, Câteau H, Fukai T, Hensch TK (2009) Bidirectional plasticity in fast-spiking GABA circuits by visual experience. Nature 462:218-221. CrossRef Medline

Yuste R, Bonhoeffer T (2001) Morphological changes in dendritic spines associated with long-term synaptic plasticity. Annu Rev Neurosci 24: 1071-1089. CrossRef Medline

Zhou Q, Homma KJ, Poo MM (2004) Shrinkage of dendritic spines associated with long-term depression of hippocampal synapses. Neuron 44: 749-757. CrossRef Medline 